\title{
Trans-Himalayan science in mid-twentieth century China and India: Birbal Sahni, Hsü Jen, and a Pan-Asian paleobotany
}

\author{
Arunabh Ghosh* (D) \\ History Department, Harvard University, Cambridge, MA, USA \\ *Author for correspondence: Arunabh Ghosh, E-mail: aghosh@fas.harvard.edu
}

(Received 13 February 2021; revised 13 May 2021; accepted 15 May 2021)

\begin{abstract}
This paper uses the decade-long collaboration between the Indian paleobotanist Birbal Sahni (1891-1949) and his Chinese doctoral student Hsü Jen (Xu Ren 徐仁, 1910-1992) to offer a connected history of midtwentieth century scientific activity in China and India. Possibly the first Chinese scientist to earn a PhD from an Indian university (Lucknow, 1946), Hsü was certainly the first to be appointed to a faculty position in India. Sahni and Hsü's attempts to build Asian networks of scientific activity, characterized by the circulation of experts, scientific knowledge, and specimens, provide the grounds for considering a practice of Pan-Asianism. Such a formulation adds to existing work on the Pan-Asianist articulations of intellectual and political figures and urges for an expansion of how we understand scientific activity across China and India from the 1930s to the 1960s. In so doing, the paper makes two historiographical interventions. In the first instance, the collaboration presents an opportunity to move beyond the two dominant frames through which histories of science in China and India are studied: the nation state and Non-West/ West binaries. Second, a focus on science widens the scope of China-India history, a field dominated by research on cultural, intellectual, and diplomatic topics.
\end{abstract}

Key words: China; continental drift; geology; history of science; India; paleobotany; Pan-Asianism

In the history of a medium known for its brevity, Birbal Sahni’s (1891-1949) telegram to Hsü Jen (Xu Ren 徐仁; 1910-1992) likely ranks amongst the tersest. Sent on December 20, 1946, its three words "Hearty Congratulations Doctorate" - meant the world to both sender and recipient. ${ }^{1}$ (Fig. 1) Sahni was among the world's foremost paleobotanists. He had sent these words to his student Hsü, who had recently returned to Beiping (present-day Beijing) after spending two and a half years studying in Sahni's lab at Lucknow University. Hsü thus became, quite possibly, the first Chinese scientist to earn a $\mathrm{PhD}$ from an Indian university. ${ }^{2}$ Within two years, Sahni enticed Hsü back to Lucknow.

\footnotetext{
${ }^{1}$ Sahni to Hsü, Telegram, 20 December 1946, Birbal Sahni Papers \#164, Nehru Memorial Museum and Library (hereafter BSP \#164), Corr. Hsu, Jen, 34. Although the modern pinyin transliteration of the name is Xu Ren, in this paper I use the original transliteration that appears in all correspondence and most published materials-Hsü Jen; except in the rare instances when a publication uses pinyin.

${ }^{2}$ The results were formally published by the Executive Council of Lucknow University on 20 December 1946 and announced in the 1948-50 Calendar. See: "Meeting Minutes of the Executive Council No. 11," Lucknow University Minutes Vol. 26, 1946-47, 371 (item 17); The University of Lucknow - Calendar 1948-50, 1, 236. Doctoral degrees were not awarded in the PRC until 1982. Eighteen of these graduates, who had received their degrees between February 1982 and March 1983, were publicly recognized at a ceremony in the Great Hall of the People in Beijing on May 26, 1983. At the ceremony, Hu Qiaomu (1912-1992) observed that no PhD degrees had been awarded prior to 1949 and a formal degree

(c) The Author(s), 2021. Published by Cambridge University Press. This is an Open Access article, distributed under the terms of the Creative Commons Attribution licence (http://creativecommons.org/licenses/by/4.0), which permits unrestricted re- use, distribution and reproduction, provided the original article is properly cited.
} 


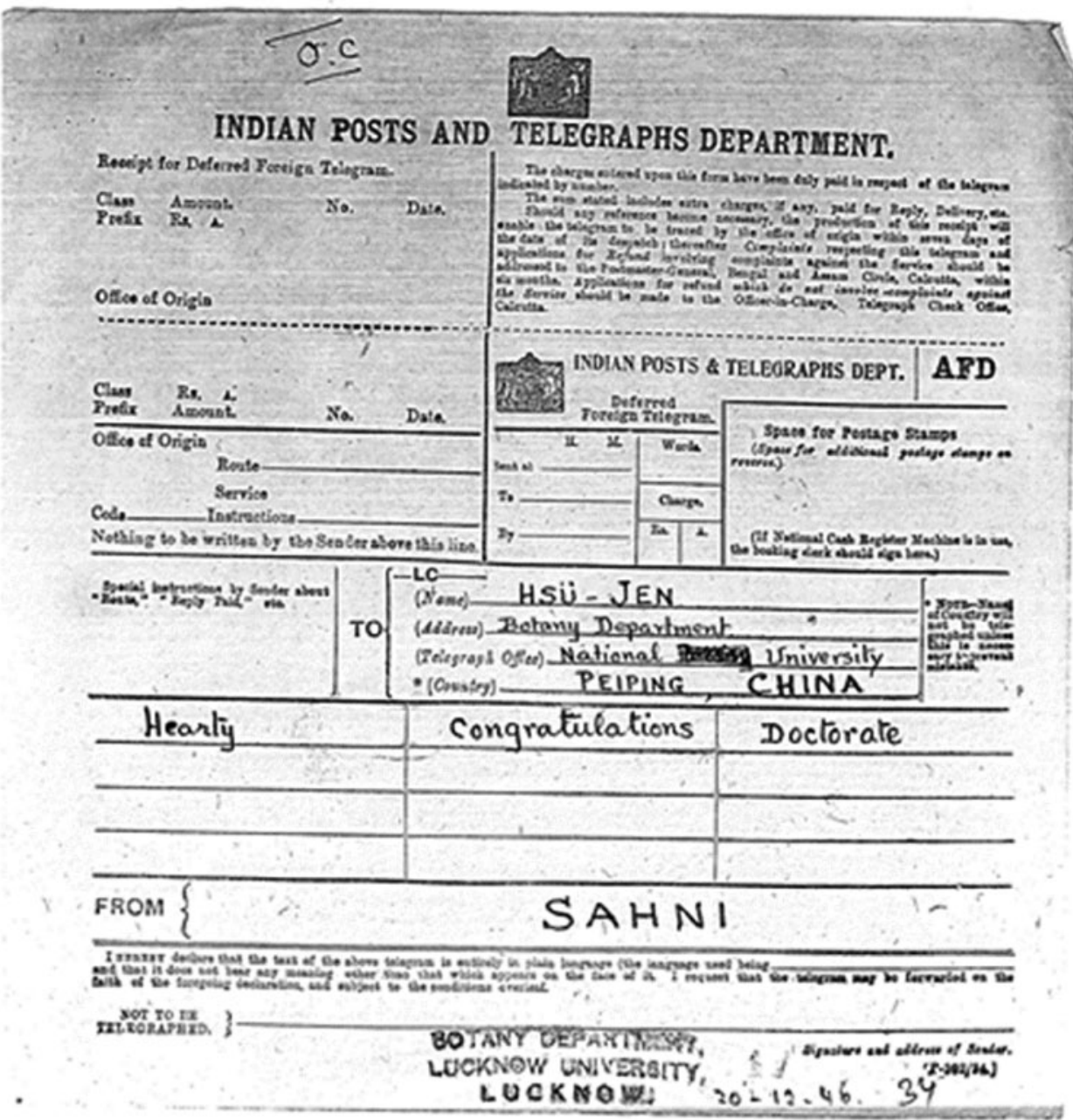

Figure 1. Original Copy of Sahni's Congratulatory Telegram to Hsü Ren.

Source: BSP \#164, Corr. Hsu, Jen, 34.

Appointed a professor and museum curator at Sahni's newly established Institute of Palaeobotany the first of its kind anywhere in the world - Hsü brought with him specimens of fossilized plant life that he had collected in China. Sahni's tragic passing within a week of laying the foundation stone for the Institute's new building in April 1949 left the fledgling institution in a precarious position. Hsü was among the group of young scientists who provided stability and leadership through this difficult phase, even representing the Institute at gatherings abroad. After four years in Lucknow, Hsü returned to Beijing, where he helped set up the Institute of Botany at the Chinese Academy of Sciences and carved out a distinguished career.

This paper reconstructs Sahni and Hsü's collaboration and uncovers the motivations that drove them. In so doing it offers alternate histories of twentieth-century China and India, which have long been mired in a civilization/realpolitik binary (Duara 2010). As a result, the majority of existing scholarship gravitates toward one of two poles: cultural and intellectual history or foreign policy and

system was only established in China in 1981. For more, see Committee on Scholarly Communication 1983, p. 25; and Yang and Yang 1983. 
geopolitics. ${ }^{3}$ A history such as this one, centered on the inter-Asian circulation of experts, scientific knowledge, and materials, also helps decenter Europe and the United States in global histories of science. Barring notable exceptions, histories of the science of China and India, are written either within primarily national contexts ${ }^{4}$ or are framed with the West (also Japan, in the case of China) as points of contact and comparison. And yet, as the case of Sahni and Hsü suggests, such a 'standard model' paints a clearly incomplete and insufficient picture of mid-century science. ${ }^{5}$

In addition to networks of scientists, the Sahni- Hsü story is also about the circulation of palaeobotanic specimens. Hsü and Sahni were avid trekkers and exchanged specimens of plant fossils collected in their native lands. Following these samples allows us to map a second set of circulations and connections (Star and Griesemer 1989). By studying these samples, which demonstrated variations in geology and plant life north and south of the Himalayas, Hsü and Sahni's were exploring an enduring problem within the discipline of geology: the validity of the then-still-controversial theory of Continental Drift. This interest in a primordial land yet to be carved up by human hands points to the alternate spatial and geographic imaginaries that exist in synchronous tension with the political realities of empires, colonies, nation states, and the world at war.

We are also at a time when historians are recognizing anew the importance of inter-Asian connections and comparisons from a variety of perspectives (Duara 2015; Harper and Amrith 2012; Ho 2017; Liu 2020, and Tagliocozzo et al. 2015). The ambition is to generate new theoretical frameworks through which to understand history, a task all the more urgent in a century when the center of geo-economic and geopolitical gravity continues to drift toward Asia. ${ }^{6}$ In that spirit, Sahni and Hsü's story offers new ways to think about Pan-Asianism. A focus on scientists and their activities provides an instance where the practice of science - carried out by scientists pursuing primarily scientific questions - also produced a form of Pan-Asianism. ${ }^{7}$ Such a formulation expands on existing work on the Pan-Asianist articulations and activities of intellectual and political figures (Saaler and Szpilman 2011, Stolte 2012, Tsui 2015).

In terms of structure, this article strikes a balance between two objectives. On the one hand, it reconstructs, in largely chronological order, the relationship between Sahni and Hsü, shedding light on topics such as institution-building, the (multi-lingual) nature of communications, scientific networks, and financial and logistical obstacles to collaboration. On the other hand, it explores the research questions that brought Sahni and Hsü together. I devote particular attention to their findings in relation to the theory of Continental Drift, a topic that would continue to drive aspects of Hsü's research well after Sahni's death. To achieve these two objectives, I rely heavily on a range of primary materials in English, Chinese, Hindi, and German. The most important among these is a trove of correspondence between Sahni and Hsü and between Sahni and several other Chinese scientists, located within the Birbal Sahni Papers at the Nehru Memorial Museum and Library in New Delhi. These

\footnotetext{
${ }^{3}$ Recent years have seen the emergence of notable exceptions that demonstrate the possibilities once we include a hitherto neglected range of actors, events, and processes. Exemplary among them are Sen 2018; Cao 2018; Tsui 2015; and Sen and Tsui 2021.

${ }^{4}$ A particularly relevant example is Grace Shen's (2014, p. 4) insightful study of "the ways in which models of science and nation converged in geological activity".

${ }^{5}$ Although imperial era networks have already received much attention (Fan 2004; Raj 2007; Schaffer et al 2009; Sen 2017), as have histories of science across 1947 and 1949 (Mullaney 2011; Phalkey 2013; Schmalzer 2016), barring the rare exception (Phalkey and Lam 2016), they remain for the most part confined to national siloes or West/Non-West binaries. Recently, Suman Seth (2017) has suggested that we apply the 'globalized' approaches of contemporary postcolonial science studies to earlier (colonial) periods. Implicit in this call is the need to bridge conventional temporal and geographic boundaries in the histories of science. Recent work in Japanese history has already begun to move in this direction, indicating rich possibilities (Kingsberg Kadia 2019).

${ }^{6}$ These approaches themselves build upon an earlier generation of critical writing, exemplary among which are Paul Cohen's ([1984] 2010) exhortation to abandon West inflected histories of China, Prasenjit Duara's (1995) appeal to rescue history from the nation, and Dipesh Chakrabarty's ([2000] 2007) call to provincialize Europe.

${ }^{7}$ Particularly salient here is Michael Gordin's (2021) reminder to pay attention not just to the public discourse about Science but also to what scientists themselves do and say about and within their specific disciplines.
} 
letters provide an intimate view of scientific relationships at a time of war and political instability. Epistolary collections apart, I also draw upon materials from the Birbal Sahni Institute in Lucknow; Lucknow University Annual Records; Hsü’s personnel file (ge ren dang'an 个人档案) from the Chinese Academy of Sciences (including multiple autobiographical essays in Hsü's own hand); Sahni and Hsü's publications; and essays by their students and colleagues.

\section{Discovering Sahni and Hsü}

Birbal Sahni is a well-known figure in the history of paleobotany and Indian science. ${ }^{8}$ Born on November 14, 1891 in Bhera in West Punjab (present-day Pakistan) to a prominent Punjabi family, Sahni's father Ruchiram Sahni would go on to serve as a professor of Chemistry at Government College, Lahore. ${ }^{9}$ His amateur scientist grandfather headed a flourishing banking business in Dera Ismail Khan. Sahni was first introduced to Botany as a student at Government College, Lahore, and he graduated with a BSc. from Punjab University in 1911. He then proceeded to Cambridge University and enrolled for the Tripos at Emmanuel College. He earned a BSc in 1914 and stayed at the University for much of the rest of the decade. It was during these years that he met and was influenced by the geologist and botanist Albert Charles Seward (1863-1941), who instilled in him a lifelong fascination for fossilized plants. ${ }^{10}$ After earning a DSc from the University of London in 1919, Sahni returned to India and held brief appointments at Benares Hindu University and Panjab University before taking up a professorship in Botany at the University of Lucknow in 1921. He remained in Lucknow for the rest of his life (Fig. 2).

At Lucknow University, Sahni pursued a rigorous research and teaching agenda that made him among the foremost paleobotanists of his age. Defined as a branch of botany that deals with extinct and fossil plants, paleobotany was a young discipline that shared close ties with geology and paleontology. ${ }^{11}$ As late as 1935, it was viewed by many as a subdiscipline of Paleontology, which "may be divided into paleobotany, treating of fossil plants, and paleozoology, treating of fossil animals" (Twenhofel and Shrock 1935). Sahni's varied contributions did much to place discoveries in India within global debates on plant origins and geological evolution. ${ }^{12} \mathrm{He}$ was one of the vice-presidents of the sections on paleobotany at the Fifth and Sixth International Botanical Congresses at Cambridge (1930) and Amsterdam (1935). In 1936, he was elected a Fellow of the Royal Society. Had he not passed away suddenly in April 1949 due to heart failure, he would have served as one of the Honorary Presidents of the Seventh International Botanical Congress in Stockholm in $1950 .{ }^{13}$ Among Sahni's institutional contributions was the world's first research institute dedicated to the study of paleobotany. Known today as the Birbal Sahni Institute of Palaeosciences, its foundation stone was laid on April 3, 1949, a week before Sahni died.

Although Sahni's biographies devote extensive space to describe his intellectual connections with scientists in Europe and the United States, they are, with one lone exception, silent about his connections with Chinese scientists. ${ }^{14}$ It was, therefore, through an altogether different chance encounter that I discovered his relationship with Hsü Ren. Some years ago, at the Institute for the History of Natural

\footnotetext{
${ }^{8}$ Sahni’s biographical details have been culled from the following sources: Hamshaw 1950; Sahni 1952; Gupta 1978; and Sharma 2010.

${ }^{9}$ Ruchiram Sahni was a prominent scientist and public intellectual in his own right. For more, see Burra 2017.

${ }^{10} \mathrm{His}$ first publication is dated to this period, an essay entitled "On the presence of foreign pollen in the ovules of Ginkgo biloba, and its significance in the study of fossil plants," and published in 1915 in the New Phytologist.

${ }^{11}$ The Oxford English Dictionary lists an earliest mention of the term, as Palæobotany, in 1872 (H. A. Nicholson Man. Palceontol. 473). Oxford English Dictionary Online. For a history of the discipline and its connections to China, see Li 1991.

${ }^{12}$ Gupta's biography lists major research and contributions in eleven areas, including Anatomy and Morphology of Palaeozoic Ferns; Gondwanaland; Theory of Continental Drift; Geology, and much else (Gupta 1978, pp. 32-63).

${ }^{13}$ For a fuller list of his honors and awards, see, inter alia Hamshaw 1950, pp. 271; Gupta 1978, pp. 69-70; and Sahni 1952, p. 3.

${ }^{14}$ The lone exception, as far as I can tell, is M.R. Sahni's biography, which mentions "Prof. Jen Hsu" twice (Sahni 1952, pp. 6, 7).
} 


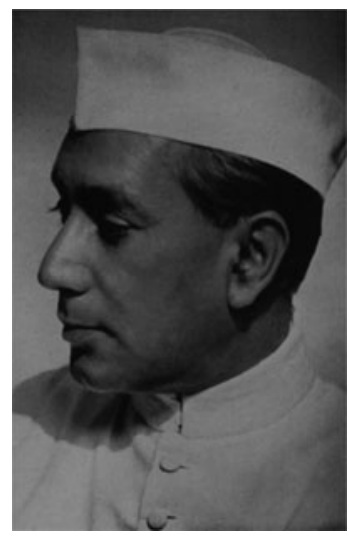

Figure 2. Birbal Sahni.

Source: Hamshaw, "Birbal Sahni."

Science in Beijing, I came across the oral history interview of the Chinese botanist Wu Zhengyi (吴征镒, 1916-2013) (Wu 1992). ${ }^{15}$ In the interview, Wu mentioned that he was part of a delegation that had attended an International Symposium on Crop Origins in New Delhi in 1951. This was the first Chinese Academy of Science delegation to visit a foreign country, he recalled (“建国后第一个出国 任务”) (Wu 1992, p. 5). The delegation was led by the botanist Chen Huanyong (陈焕锯, 18901971) ${ }^{16}$ and included three other members: the ecologist Hou Xueyu (侯学煜, 1912-1991), the plant physiologist Yin Hongzhang (殷宏章, 1908-1992), and the paleobotanist Hsü Jen. As I dug deeper, I discovered that unlike his fellow delegates, who had traveled from China, Hsü had taken the train up from Lucknow. And so began my exploration of Hsü's activities (Fig. 3).

Hsü Jen was born in 1910 into a family of merchants and officials in the city of Wuhu (芜湖) in Anhui province. ${ }^{17}$ By the time he entered his teens, the family's fortunes had begun to suffer. Things got worse when, at the age of fourteen, he lost his father and became dependent on the financial assistance of relatives. A good student, he entered Tsinghua in 1929 and was inspired by the botanist C.Y. Chang to study science. ${ }^{18}$ After graduating with a degree in Botany in 1933, he served as a teaching assistant at Peking University's Biology Department from 1933 to 1938. It was during these years that he began to undertake research in paleobotany. In 1937, he moved with the University as it joined with Tsinghua and Nankai to form Southwest Associated University (西南联合大学), first in Changsha and then in Kunming. During 1938-1939, he was a research fellow in Botany, funded by the British Boxer Indemnity Fund, and from 1939 to 1943 he taught as an associate professor at Yunnan University in Kunming. It was around this time that he established contact with Sahni, eventually joining him in Lucknow in January 1944. Hsü received his doctorate in 1946 and spent two years as an associate professor at Peking University before returning to Lucknow in 1948 to take on a professorship at the newly established Institute of Palaeobotany. Aside from Sahni, he was the only other full professor at the Institute. Hsü returned to China in early 1952, serving initially as a

\footnotetext{
${ }^{15} \mathrm{Wu}$ was China's foremost plant taxonomist and the longtime director of the Kunming Institute of Botany. For a brief biography, visit: http://flora.huh.harvard.edu/china/mss/wuzhengy.htm. The journal Plant Diversity devoted a special section in his memory in 2016 (Anon. 2016).

${ }^{16}$ On Chen, see Haas 1988 and Huang 2016.

${ }^{17} \mathrm{H}$ sü's biographical details are drawn from the following sources: (1) Xu Ren Personnel File (个人档案), in the author's personal collection; (2) Xu 2000b; (3) Li 1993; (4) Hsü’s CV ca. 1942, located in BSP \#164, Subj. File 60, 117.

${ }^{18}$ One of China's premier botanists, C.Y. Chang (Zhang Jingyue 张景钱, 1895-1975) was educated at Tsinghua School (the precursor to Tsinghua University), graduating in 1920. He then traveled to the United States, enrolling first at Texas A\&M University, and in 1922 at the University of Chicago's Department of Botany. He received an MSc in 1923 and a $\mathrm{PhD}$ in 1925. Upon his return to China he taught Botany at universities in Nanjing, Beijing, and Kunming. From 19301932 he conducted research for two years in Europe (at the Universities of Leeds and Basel). In late 1945, he traveled to the United States and spent a year as a visiting professor at the University of California at Berkeley. For more on Chang and his career, see: (1) Ge 1997; and (2) Anon. 2012.
} 
Figure 3. Hsü shortly after arriving in Lucknow, 14 March 1944. Source: Xu 2000a.

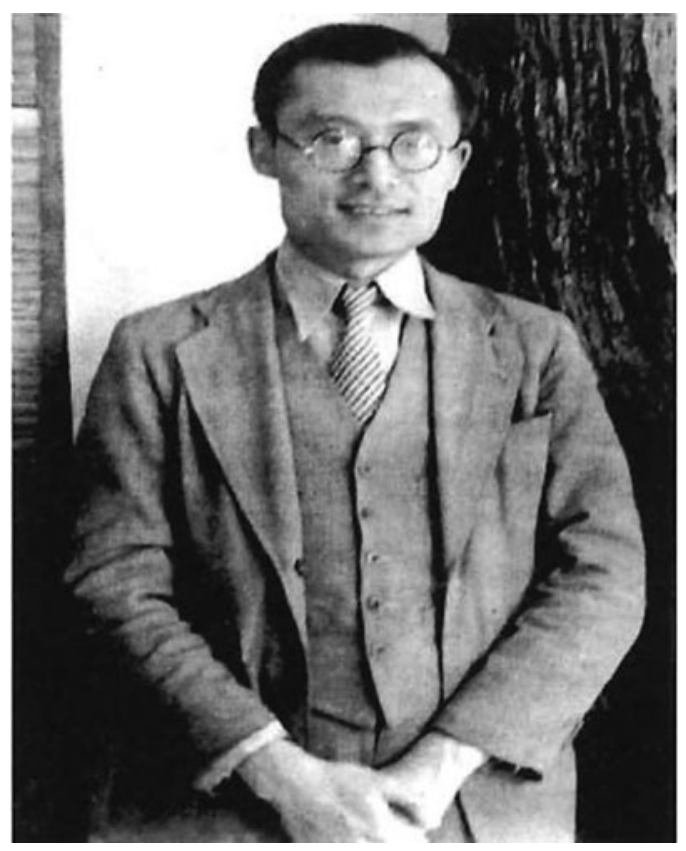

researcher in the Ministry of Geology. In 1959, he helped set up the Institute of Botany at the Chinese Academy of Sciences and moved there permanently in 1962.

\section{Sahni's China connections}

Sahni's contacts with Chinese scientists far predated his taking Hsü on as a student. But most of these contacts had been snapped by the late 1930s. In April 1938, Sahni drafted a letter to the Bureau of International Exchange of the Chinese Ministry of Education, explaining that "[o]wing to the war in China I have, unfortunately, got out of touch with all my colleagues working in Botany, Geology and Paleobotany." ${ }^{19}$ He went on to list several prominent Chinese scientists in the hopes that the Bureau might help him reestablish contact: "Dr. H.H. Hu. Fan/Tau Memorial Institute; Prof. C. Y. Chang (Botanist); Prof. H.C. Hsieh (Paleobotanist); Prof. Sze (Paleobotanist) ${ }^{20}$; Prof. J.S. Lee (Geologist); Prof. A.W. Grabau (Geologist); Prof. W.H. Wong (Geologist) ${ }^{21}$; and Prof. V.K. Ting (Geologist) ${ }^{22}$." Sahni also requested membership rolls for "the Science Society of China, the Geological Society of China, The Fan Memorial Institute and any of the other important scientific Institutes..."23

Among Sahni's earliest correspondents were the scientists H.C. Sze, C.Y. Hsieh, and W.H. Wong, with whom he exchanged reprints of articles and discussed works-in-progress starting in the early

\footnotetext{
${ }^{19}$ Bureau of International Exchange to Sahni, 12 April 1938, BSP \#164, Corr. Bureau of International Exchange, China [\#580] (see handwritten annotation starting on p. 1 and continuing onto the back).

${ }^{20}$ Si Xingjian (斯行健, 1901-1964).

${ }^{21}$ Weng Wenhao (翁文影, 1889-1971), one of the founding fathers of modern Geology in China. For more, see Shen 2014.

${ }^{22}$ Ding Wenjiang (丁文江, 1887-1936), another prominent Chinese geologist. For more, see Shen 2014 and Fiskesjö 2011.

${ }^{23}$ Bureau of International Exchange to Sahni, 12 April 1938, BSP \#164, Corr. Bureau of International Exchange, China [\#580]. Sahni appears not to have solved the problem. In late 1942 he wrote to Shen Shi-hua, the Chinese Commissioner in India with a similar request, listing the following scientists: 1. Dr. W.H. Wong, Director, Geological Survey of China; 2. Prof. J.S. Lee, Professor of Geology, Academia Sinica; 3. Dr. C.Y. Hsieh, Geological Survey of China; 4. Dr. T.C. Chow, Geological Survey of China; 5. Dr. T.K. Huang, Geological Society of China; 6. Dr. H.C. Sze, formerly at the National University. See: Sahni to Shen, 17 December 1942, BSP \#164, Corr. Shen-Shi-Hua, 2.
} 
1930s. ${ }^{24}$ Sahni and his Chinese interlocutors were a cosmopolitan bunch, frequently in different parts of the world, and their letters and postcards trace global circuits that connected Lucknow, Beiping (Beijing), and Nanking (Nanjing) to Stockholm, Cambridge (UK), and Berkeley. ${ }^{25}$ A likely and important point of early contact was the Fifth International Botanical Congress in Cambridge (UK), which was held from August 16 to 23, 1930 and had a dedicated symposium on the flora of China. ${ }^{26}$ The conference was unprecedented in its scale, with nearly 1,000 attendees and a much wider international representation than had heretofore been achieved. Chinese participants included the botanists Chen Huanyong and C.Y. Chang. Sahni presented a paper in the paleobotanical section, which was attended by C.Y. Chang, who wrote glowingly about it to Sahni later in the year. ${ }^{27}$

Although the letters between Sahni and his Chinese colleagues ordinarily focused on research-related topics, they frequently also veered into contemporary affairs, suggesting sensitivity to larger political events. ${ }^{28}$ For instance, H.C. Sze wrote to Sahni in 1937 describing his recent work on "Gigantopteris-Flora." 29 Gigantopteris-Flora was the early name given to a large variety of Asian gigantopterids. ${ }^{30}$ As we shall see, these floras would go on to play a significant role for Sahni and Hsü. But Sze also wrote of his dismay with political events in China. In 1932, shortly after the Japanese takeover of Manchuria, he had concluded a postcard to Sahni thus: "[d]uring this critical time of our country I have indeed no pleasure, to work the fossil plants [sic] which is absolutely useless for "Verteidigung unseres Vaterlandes"!!! [the defense of our Fatherland]."31 Sze's letters were often drafted in German or a mixture of English and German. ${ }^{32}$ Five years later, he wrote with even greater despondence of "political catastrophe," referring to the war with Japan, and of his consequent loss of interest in traveling to India to attend the Indian Science Congress. ${ }^{33}$ In his reply, Sahni expressed solidarity with China's travails and hoped that there would be "more occasions to bring Chinese and Indian scientists into personal contact." ${ }^{34}$

Sahni's most enduring and significant correspondent - at least for our purposes - was C.Y. Chang, with whom he exchanged letters as early as 1930. One of China's premier botanists, Chang was then on a two-year visit to Europe, splitting his time between the Universities of Leeds and Basel. Chang and Sahni had likely encountered each other at meetings in Europe. In a letter written in early December 1930 from Leeds, Chang sought Sahni's comments on a paper he had written on Pteris, explaining, "I shall be glad to have your criticism on the former paper...Like everyone else who attended the paleobotanical section meetings at Cambridge, I was very impressed with that marvelous piece of petrified angiosperm wood." ${ }^{35}$ After corresponding for a decade and a half, the two finally met

\footnotetext{
${ }^{24}$ Wartime made such exchanges increasingly difficult, but Sahni and his Chinese colleagues did not let their efforts flag. For example, in a letter written on 23 June 1944, C.Y. Chang thanked Sahni for a "big package of 31 reprints of your scientific papers." Chang to Sahni, 23 June 1944, BSP \#164, Subj. File 60, 95.

${ }^{25}$ See, for instance: (1) Wong to Sahni, 25 January 1930, BSP \#164, Corr. National Geographic Survey of China, Director of., from Peiping; (2) Wong to Sahni, 1 December 1935, BSP \#164, Corr. National Geographic Survey of China, Director of, from Peiping; (3) Sze to Sahni, 2 January 1932, BSP \#164, Nanking, National Research Institute of Geology, 1.

${ }^{26}$ On the conference, see Anon. 1930; on Chen's participation, see Haas 1988. Zhang mentioned his own participation in a letter to Sahni, 3 Dec. 1930, BSP \#164, Corr. Chang, C.Y., 1.

${ }^{27}$ Chang to to Sahni, 3 Dec. 1930, BSP \#164, Corr. Chang, C.Y., 1-2.

${ }^{28}$ Shen (2014) offers a nuanced and insightful treatment of the intertwining of science and nationalism in the field of Geology.

${ }^{29}$ Sze to Sahni, 7 August 1937, BSP \#164, Nanking, National Research Institute of Geology, 4-5.

${ }^{30}$ Gigantopterids are fossils of a group of plants from the Permian period, which is dated from 298.9 million years ago to 251.9 million years ago. The Permian is sandwiched between the earlier Carboniferous and later Triassic periods. For more, see: https://stratigraphy.org/timescale/ (accessed 22 December 2020)

${ }^{31}$ Sze to Sahni, 2 January 1932, BSP \#164, Nanking, National Research Institute of Geology, 1.

${ }^{32}$ On the multilingual nature of scientific discourse during this era, see Gordin 2015.

33"Durch die leisige [sic] politische Katastrophe habe ich die Lust verloren nach Indian zu kommen, und die Indian Science Congress teil zunehmen." Sze to Sahni, 7 August 1937, BSP \#164, Nanking, National Research Institute of Geology, 4-5.

${ }^{34}$ Sahni to Sze, 6 September 1937, BSP, Nanking, National Research Institute of Geology, 6.

${ }^{35}$ Chang to Sahni, 3 December 1930, BSP \#164, Corr. Chang, C.Y., 1-2, 3.
} 
in late 1945, when Sahni hosted Chang in Lucknow for a few days. ${ }^{36}$ Chang was then en route to the United States and, as was the norm in those days, had broken his journey in Calcutta to change ships. His Calcutta sojourn eventually lasted twenty days, during which time he along with other Chinese scientists visited botanical labs and other scientific institutions, including P.C. Mahalanobis' Indian Statistical Institute. ${ }^{37}$ Impressed, Chang wrote to Sahni, "India is far more advanced than we in science and technology and we have a great deal to learn from her. I sincerely hope that the good contact between us made in war will be maintained in future." 38

Chang's experience in Calcutta was hardly unique. The city served as a port of call for a whole generation of Chinese scientists traveling West during the 1930s and 1940s. Some only stayed a day or two, but in many instances, their itineraries and the nature of war-time travel meant an extended sojourn, thereby offering the possibility for some sustained intellectual exchanges. C.N. Yang (杨振宁; 1922 -), the 1957 Nobel laureate in Physics, recalled spending a few weeks in Calcutta in 1945 or 1946 en route to the University of Chicago. During his stay, he met with the Indian physicist M.N. Saha (18931956). Similarly, the mathematician Shiing-Shen Chern (Chen Xingshen 陳省身; 1911-2004) flew from Kunming to Calcutta on July 15, 1943. His two-week stay included four lectures at the University of Calcutta. Chern then proceeded to Karachi and arrived eventually in Miami in August of that year (Wang and Guo 2019, p. 130). The city was thus an important node in transnational scientific endeavors that linked China with India and Asia with Anglo-European centers of knowledge further west.

One beneficiary of the good contact that Chang celebrated was Hsü Jen. It was Chang who had introduced Hsü to Sahni in the early 1940s and recommended that he work in Sahni's lab. ${ }^{39}$ In a letter written after Hsü's arrival in Lucknow, Chang thanked Sahni for helping Hsü, "for in helping him you are helping China to get started in paleobotanical researches...There is not the slightest doubt that he is getting more profit from you than he could get from any European or American scientist." ${ }^{\text {"0 }}$ In his personnel dossier, Hsü would identify Chang as the close friend and teacher who had the greatest influence upon him. ${ }^{41}$ After Hsü's return to China, Chang would see to it that he was appointed an assistant professor of paleobotany so that he could help establish the discipline in China. ${ }^{42}$ Chang was both grateful and frank with Sahni. From his sabbatical in Berkeley in 1946, he wrote: "Chinese botany is indebted to you for the careful training you have given him. I feel sure that he will acquit himself well and make good use of his training." ${ }^{33}$ A year earlier, he had explained to Sahni that "Mr. Hsu [sic] retains a good deal of childish simplicity, but, I am afraid, he is sometimes childish. Please be very frank with him, be his master as well his teacher and patron saint." ${ }^{44}$

\section{Getting Hsü to India}

By the end of 1942, Sahni and Hsü were in regular correspondence. Sahni had also agreed in principle to host Hsü. "It would give us much pleasure to have you working here, and to introduce you to some of our rich plant-bearing strata," Sahni had written, adding that "if you are able to spend about two

\footnotetext{
${ }^{36}$ According to a letter Sahni wrote to the Indian statistician P.C. Mahalanobis, Chang was in Lucknow from Oct. 29 to Nov. 1. See: Sahni to PC Mahalanobis, 2 November 1945, BSP \#164, Corr. Mahalanobis, P.C. [\#2097-2109], 9-10. Chang recalled the visit fondly in his valediction to Sahni in the Palaebotanist's inaugural volume (Hsü et al. 1952, pp. 490-491). He had also hoped to bring Sahni to China after the war for a year or two (Chang to Sahni, 11 May 1944 , BSP \#164, Subject File 60, 92-93).

${ }^{37}$ See, for instance: Chang to Sahni, BSP \#164, Corr. Chang, C.Y., 7 Nov 1945, 12-13A; Chang to Sahni, BSP \#164, Corr. Chang, C.Y., 15 Nov 1945, 14-15.

${ }^{38}$ Chang to Sahni, BSP \#164, Corr. Chang, C.Y., 7 Nov 1945, 12-13A.

${ }^{39}$ Chang to Sahni, 11 May 1944, BSP \#164, Subject File 60, 92-93.

${ }^{40}$ Chang to Sahni, 11 May 1944, BSP \#164, Subject File 60, 92-93. The last bit may well have been strategic flattery. For instance, Sun Qigao notes that Chang had originally hoped that Hsü would study paleobotany with John Walton (18951971) at Glasgow University, but the war and financial difficulties intervened (Sun 2009).

${ }^{41}$ Xu Ren, Personnel Dossier (个人档案), 14.

${ }^{42}$ Chang to Shani, 5 July 1945, BSP \#164, Corr. Chang, C.Y., 7.

${ }^{43}$ Chang to Sahni, 15 Feb 1946, BSP \#164, Corr. Chang, C.Y., 16-16A.

${ }^{44}$ Chang to Sahni, 5 July 1945, BSP \#164, Corr. Chang, C.Y., 7.
} 
years here it should be possible for you to do a substantial piece of work, which could be presented for a $\mathrm{PhD} .{ }^{45}$ It would, however, require a fair amount of wrangling with administrative, financial, and logistical issues before Hsü was finally able to arrive in Lucknow a little over an year later in early 1944. Administrative issues at the university level were the easiest to resolve. Although Sahni sent the relevant university regulations to Hsü, he also assured him that many requirements for matriculation to the $\mathrm{PhD}$, such as an MSc degree or a minimum number of terms, could be waived. Further, as a research student, Hsü was free to matriculate at his convenience and not necessarily at the start of term. ${ }^{46}$

Financial considerations proved far more intractable. ${ }^{47}$ An early hope was that Hsü might be selected by the Government of China as part of a recently established exchange program between China and India. Under this program, ten Chinese students would receive fellowships to study in India, with the Indian Government covering fees, travel, and a living stipend of INR 200 per month. ${ }^{48}$ In the event, Hsü was not selected for the fellowship and Sahni was forced to expend significant social capital raising funds on his behalf. ${ }^{49}$ From Lucknow University Sahni was able secure a waiver for all associated matriculation fees as well as a fellowship of INR 100 per month. ${ }^{50} \mathrm{He}$ also approached Panna Lall, an advisor to the government of the United Provinces, as well as John Sargent, the Educational Commissioner of the Government of India, for additional financial help. ${ }^{51}$ These efforts eventually bore fruit. By October 1944, Sahni was able to inform Chang that they had secured a monthly stipend of INR 200 for Hsü, which he hoped would continue into a second year. ${ }^{52}$

The final set of hurdles involved administrative and logistical issues with the governments of both China and India. Hsü had originally hoped to be in India by August 1942 but these hopes were quickly dashed. ${ }^{53}$ The first obstacle he encountered was getting permission from the Chinese Ministry of Education to obtain a passport. After significant delays, he managed to acquire both by June $1943 .{ }^{54}$ But he still needed a visa from the Indian Government. Sahni again sought help from John Sargent, the Educational Commissioner, and Panna Lall, advisor to the UP Government. ${ }^{55}$ By early October, Hsü had been waiting for nearly four months and was increasingly concerned: "I am now held in suspense. I have resigned my post in the University of Yunnan as there is an understanding between the University of Peking and myself to the effect that I join that University upon my return

\footnotetext{
${ }^{45}$ Sahni to Hsü, 18 November 1942, BSP \#164, Subj. File 60, 2.

${ }^{46}$ See, for instance, Sahni to Hsü, 24 December 1942, BSP \#164, Subj. File 60, 13; Sahni to Hsü, 18 November 1942, BSP \#164, Subj. File 60, 2; BSP \#164, Subj. File 60, 24-25.

${ }^{47}$ About a decade and a half later, the Indian demographer Sripati Chandrasekhar would encounter similar funding challenges (Ghosh 2017, pp. 716-717).

${ }^{48}$ An undated handwritten draft by Sahni to Hsü explains that he would need at least INR 180 per month to live comfortably in Lucknow (that is, not in a hostel). Sahni to Hsü, undated, BSP \#164, Subj. File 60, 15. A history of this formal government to government scientific exchange program remains to be written.

${ }^{49}$ Hsü to Sahni, 8 March 1943, BSP \#164, Subj. File 60, 31.

${ }^{50}$ Sahni to Hsü, 5 December 1942, BSP \#164, Subj. File 60, 5-6.

${ }^{51}$ Sahni to Sargent, 18 November 1942, BSP \#164, Subj. File 60, 4; Sahni to Vice-Chancellor, 23 December 1942, BSP \#164, Subj. File 60, 11; Sahni to Panna Lall, 23 December 1942, BSP \#164, Subj. File 60, 13; Lucknow University Vice-Chancellor Bisheshwar Dayal Seth to Panna Lall, 20 May 1943, BSP \#164, Subj. File 60, 40.

${ }^{52}$ Sahni to Chang, 14 October 1944, BSP \#164, Subj. File 60, 104. The 1946 Annual Report of Lucknow University listed Hsü as a PhD student of Birbal Sahni's and noted that the Fellowship granted him in 1945 had been extended until 15 April 1946. See: Annual Report 1946, University of Lucknow, 28 March 1947, 12, 14. And on 20 December 1946 the Executive Council of Lucknow University noted that Hsü's INR 200 per month stipend had been extended for a further two and a half months. See: "Meeting Minutes of the Executive Council No. 11," Lucknow University Minutes Vol. 26, 1946-47, 90 (Appendix A).

${ }^{53}$ Sahni to Hsü, 10 August 1942, BSP \#164, Subj. File 60, 1.

${ }^{54}$ Hsü subsequently wrote to Sahni in July 1943 to confirm that he had a passport. In his memoirs, Hsü explained the delay in issuing a passport was because he refused to join the Nationalist Party (Guomindang). Eventually, he was issued a student passport. Ou to Sahni, 14 June 1943, BSP \#164, Subj. File 60, 41; Hsü to Sahni, 27 July 1943, BSP \#164, Subj. File 60, 44; Xu 2000b, p. 315.

${ }^{55}$ Sahni to Sargent, 28 August 1943, BSP \#164, Subj. File 60, 47; Sahni to Panna Lall, 10 September 1943, BSP \#164, Subj. File 60, 49
} 
from India. At present, I am without a position and without work." ${ }^{56}$ The delay was classically bureaucratic: the central government wanted an assurance from the UP government that Hsü had sufficient resources to maintain himself in India and a repatriation plan in the event of a crisis. This the University finally guaranteed toward the end of October. ${ }^{57}$ And so, on November 14, 1943, Hsü wrote Sahni to say that his visa had been granted, but because he had begun to teach a course in the agricultural college, he would not be able to travel to India until January $1944 .^{58}$

\section{Doctoral days}

Hsü arrived in Calcutta on January 27, 1944 and proceeded to Lucknow on the Punjab Mail two days later. ${ }^{59}$ A few weeks later, Sahni wrote to the Lucknow University Vice-Chancellor informing him that Hsü had been working in his lab since January $31 .^{60}$ It is clear that he quickly made a strong impression on Sahni, who wrote to C.Y. Chang in July:

[I]t is a real pleasure to have Professor Hsü with us...He has made himself popular all round. With his broad-based training, his remarkable industry and his receptive mind he has already made very good use of his time. During this [summer] vacation he has concentrated on improving his English, and I think he has done well. ${ }^{61}$

English would remain a challenge for Hsü and although his letters display an effective command of the language, he was never able to rid his writing of infelicities. ${ }^{62}$ A second challenge was the Indian weather. Later that fall, Sahni wrote to C.Y. Chang:

I am glad to tell you that he has on the whole stood the Indian climate quite well, though the summer was very trying for him at first. In fact, he has gained in weight and is looking distinctly better than he first came here. He has also made good progress with the English language. ${ }^{63}$

By August, Hsü was deeply immersed in his work, requesting process plates and sheets of bromide paper for his research. ${ }^{64}$ Much of his lab work involved working with samples he had brought with him from China. Prominent among these were samples of Gigantopteris flora from Yunnan, which he described and compared with specimens from other parts of Asia:

Today I have finished the description of Gigantopteris flora specimens. From tomorrow I will discuss their relations with Sumatra, Indian and Central Shansi and Honan flora. It definitely shows no relation with Indian permo carboniferous flora and makes the link between Sumatra and North Chinese flora. Totally, 34 specimens have been recorded (some with seeds). I think I have try [sic] my best to search them out for the fragments. I do hope, this coming half a month I will find the Rhaetic flora part. ${ }^{65}$

\footnotetext{
${ }^{56} \mathrm{Hsü} \mathrm{to} \mathrm{Sahni,} 1$ October, BSP \#164, Subj. File 60, 61-62.

${ }^{57}$ Sahni to Hsü, Telegram, 26 October 1943, BSP \#164, Subj. File 60, 67.

${ }^{58}$ Hsü to Sahni, 14 November 1943, BSP \#164, Subj. File 60, 71.

${ }^{59}$ Hsü to Sahni, Telegram, 27 January 1944, BSP \#164, Subj. File 60, 75.

${ }^{60}$ Sahni to Vice-Chancellor, 26 February 1944, BSP \#164, Subj. File 60, 77.

${ }^{61}$ Sahni to Chang, 2 July 1944, BSP \#164, Subj. File 60, 96.

${ }^{62}$ One of Hsü's external $\mathrm{PhD}$ examiners would note numerous errors in his thesis as well, ascribing them to a "lack of familiarity with the English language". Arnold to Registrar, University of Lucknow, 18 October 1946, BSP \#164, Corr. Hsu, Jen, 39-41.

${ }^{63}$ Sahni to Chang, 14 October 1944, BSP \#164, Subj. File 60, 104.

${ }^{64}$ Hsü to Dean of Faculty of Science (Sahni), 14 August 1944, BSP \#164, Subj. File 60, 99.

${ }^{65}$ Hsü to Sahni, 12 August 1945, BSP \#164, Corr. Hsu, Jen, 6-8.
} 
The work on Gigantopteris would figure as the fifth and final chapter of his doctoral thesis and Sahni and T.G. Halle (1884-1964) would both be very pleased with it. ${ }^{66}$ In 1944, Hsü received further recognition when his work on Devonian spores (泥盆纪孢子 nipenji baozi) was awarded a University Research Award. ${ }^{67}$

Sahni had been keen for Hsü to bring with him paleobotanical samples from China. And he was quite specific about what would be of greatest interest: "If you can bring any material at all please do not trouble about Tertiary fossils. Devonian material would be interesting even if poorly preserved. Jurassic plants from China should be specially interesting for comparison with the Indian upper Gondwana floras." ${ }^{\prime 8}$ Hsü had been worried about how much he would realistically be able to bring given that he planned to fly to Calcutta and extra air freight would likely be exorbitant. ${ }^{69}$ In the event, he did bring with him, at considerable personal expense, several samples of fossil plants collected from Yunnan. ${ }^{70}$ Having worked on them during his time in Lucknow, he left them behind as a gift when he returned to China in April 1946. These included Devonian plants, Brown Shale, Permian plants from the Huitsch District, Rhaetic plants, and two pieces of Tertiary wood. ${ }^{71}$ A grateful Sahni returned the favor some months later, gifting specimens of Otomazite pecten, Glossopteris, Schizoneura gondwanensis, and Homoxylon rajmahalense, that he and his colleagues had collected over the years. ${ }^{72}$

In addition to lab work, Hsü also participated in treks through the Himalayas with Sahni and other scientists. An avid trekker since his childhood, Sahni frequently undertook such treks, both for pleasure and to collect specimens. ${ }^{73}$ In the summer of 1944 (May-June), Sahni, Hsü, and their colleague Dr. R.D. Misra, made a trek "between Gujrat, Bhimbar, Nowshera, Rajauri, Thanamandi, Poonch, Aliabad, Uri and finally Srinagar." ${ }^{74}$ To escape the heat wave in the plains, Hsü spent much of the summer of 1945 in the hill station of Almora (in the present-day state of Uttarakhand). ${ }^{75} \mathrm{He}$ also made fast friends in Lucknow, recalling them by name in correspondence after his departure. ${ }^{76}$ By the end of his stay in India, Sahni too had grown fond of the man, beginning to refer to him simply as "My dear Hsü," instead of the more formal "Dear Professor Hsü". ${ }^{77}$ Hsü's own affection for Sahni and his wife is evident from a letter written to the latter after his return to Beijing: "Last night, I dreamed I was still sleeping in your house. It seems you and Professor were resting on the upper floor. The moon light was so bright."78

In the spring of 1946, Hsü submitted his PhD thesis and returned home to China. His thesis consisted of five chapters:

(1) Search for Microfossils in the Purple Sandstone

(2) Plant fragments from Devonian Beds in Central Yunnan, China

(3) Plant Microfossils from Devonian rocks at P'oshi, in the District of Lishien, Central Yunnan, China

(4) Plant Microfossils from Brown Shales in the District of Lunan, Central Yunnan, China

(5) Some Permian plants from the Huitsch District, North-Eastern Yunnan, China ${ }^{79}$

\footnotetext{
${ }^{66}$ Sahni to Hsü, 25 November 1946, BSP \#164, Corr. Hsu, Jen, 29-30.

67“全校研究奖奖章” (Xu 2000b, p. 315).

${ }^{68}$ Sahni to Hsü, 24 December 1942, Subj. File 60, 13-14.

${ }^{69}$ See, for instance, Hsü to Sahni, 17 December 1942, Subj. File 60, 9-10.

${ }^{70}$ Sahni to Vice-Chancellor, 26 February 1944, BSP \#164, Subj. File 60, 77.

${ }^{71}$ Hsü to Sahni, 15 April 1946, BSP \#164, Corr. Hsu, Jen, 9.

72"Fossil specimens handed over to Prof. J. Hsu," undated, BSP \#164, Corr. Hsu, Jen, 38.

${ }^{73}$ See, inter alia, Gupta 1978, pp.14-16; and Sahni 1952, p. 5.

${ }^{74}$ Sahni 1952, p. 6; Sahni to Hsieh, 3 July 1944, BSP \#164, Subj. File 60, 97; Xu 2000b, p. 315. Hsü also wrote to C.Y. Chang about this trip (Chang to Sahni, 10 September 1944, BSP \#164, Subj. File 60, 103).

${ }^{75}$ Hsü to Sahni, 28 July 1945, BSP \# 164, Corr. Hsu, Jen, 4-5; Hsü to Sahni, 12 August 1945, BSP \#164, Corr. Hsu, Jen, 6-8.

${ }^{76}$ "Kindly convey my best regards to Sitholey, Surange, Trivedi, Kaul, Venkatachary, Lakhanpal, Saksena and other members of the Palaeobotanical Section.” Hsü to Sahni, 27 July 1946, BSP \#164, Corr. Hsu, Jen, 13-15, see 15.

${ }^{77}$ Sahni to Hsü, 8 May 1946, BSP \#164, Corr. Hsu, Jen, 28.

${ }^{78} \mathrm{Hsü} \mathrm{also} \mathrm{enquired} \mathrm{after} \mathrm{her} \mathrm{health.} \mathrm{Hsü} \mathrm{to} \mathrm{Savitri} \mathrm{Sahni,} 8$ September 1946, BSP \#164, Corr. Hsu, Jen, 22.

${ }^{79}$ BSP \#164, Corr. Hsu, Jen.
} 
In his role as the internal examiner, Sahni judged the thesis excellent and noted that "[w]orking in my laboratory for a period of a little over two years Mr. Hsü, who came here with no previous training in fossil botany, has produced a series of original papers which would do credit to many an experienced palaeobotanist." ${ }^{\text {"80 }}$ Hsü's external examiners were C. A. Arnold (1901-1977), an associate professor of Botany and curator of Paleobotany at the Museum of Botany at the University of Michigan, and the Swedish botanist T. G. Halle. Although both Arnold and Halle provided detailed comments and disagreed on many of the finer points (Halle in particular), they were both sufficiently impressed to recommend that Hsü be granted the degree without further examination. ${ }^{81}$ By the time Sahni sent his three-word congratulatory telegram in December 1946, Hsü had been back in China for nearly eight months. ${ }^{82}$

\section{Institution-building during a return to India}

Hsü and Sahni remained in touch following his departure from Lucknow. In late 1946, Sahni informed Hsü that he had been made the first non-Indian member of the recently established Palaeobotanical Society. ${ }^{83}$ In Beiping, Hsü found the going tough. Although the Second World War had ended, its eight years had left China in a perilous state. Compounding affairs was the civil war that had broken out between the Nationalists and the Communists earlier in the year. In September 1946, Hsü had written to Sahni, complaining that no field work was possible because of the war. Financial conditions were also dire, with inflation rampant. In the midst of these troubles, Hsü still longed to do research and expressed a desire to work on the environment of the recently discovered Peking Man. But he also clearly missed being in Lucknow. ${ }^{84}$ By 1947, the situation was significantly worse. In January, he wrote that he was "very happy and willing to come to India again. I need more training + I wish to stay in India for some time. If China is still in Civil War, I would like to settle in India. For there is hope [sic], there is life." ${ }^{85}$ Several months later, his frustrations were further compounded when he was denied permission to pursue fieldwork in southwest China. A lack of teaching staff - many foreign teachers had chosen to delay their return to Beiping - meant additional burdens on those who were available, he explained. ${ }^{86}$

Faced with such increasingly difficult circumstances, the prospect of returning to India must have been an appealing one. Sahni had first floated the idea in late 1946, when he wrote to update Hsü on the Palaeobotanical Institute he hoped to set up. Sahni told Hsü about his plans to acquire a rectangular area for the Institute measuring 425 feet by 700 feet. He then enticingly added: "I look forward to welcome you as one of the workers at the Institute...Will you come if invited?" ${ }^{87}$ Some months later, he wrote more forcefully and more formally:

Sometime in 1948, we may formally open the Institute, of which the nucleus, as you know, already exists and is active here in the department itself. We hope that on that occasion at least, if not earlier, you will be again in India. There will be a place for you here always. We can offer you a post, say, as Curator of the Museum, with research duties, and a pay of about R. 500/- per month; but please write early, so that I know well before our departure [on an inter-

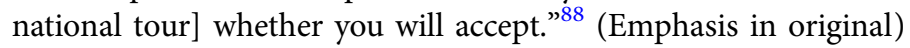

\footnotetext{
${ }^{80}$ Birbal Sahni, "Report of the Internal Examiner on the Thesis by Mr. Jen Hsü for the degree of Ph.D. at Lucknow," 20 May 1946, BSP \#164, Corr. Hsu, Jen, 35-37.

${ }^{81}$ Arnold to Registrar, University of Lucknow, 18 October 1946, BSP \#164, Corr. Hsu, Jen, 39-41; Halle, "Report on Mr. Jen Hsü's thesis for the degree of Doctor of Philosophy," 15 November 1946, BSP \#164, Corr. Hsu, Jen, 42-56 (two copies of the report, and one copy of page-level comments).

${ }^{82}$ Hsü had arrived back in China on 27 April 1946. Hsü to Sahni, 26 April 1946, BSP \#164, Corr. Hsu, Jen, 12.

${ }^{83}$ Sahni to Hsü, 25 November 1946, BSP \#164, Corr. Hsu, Jen, 29-30 (see 30).

${ }^{84}$ Hsü to Sahni, 8 September 1946, BSP \#164, Corr. Hsu, Jen, 18-21.

${ }^{85}$ Hsü to Sahni, 26 January 1947, BSP \#164, Corr. Hsu, Jen, 24-25.

${ }^{86}$ Hsü to Sahni, 6 September 1947, BSP \#164, Corr. Hsu, Jen, 26.

${ }^{87}$ Sahni to Hsü, 25 November 1946, BSP \#164, Corr. Hsu, Jen, 29-30.

${ }^{88}$ Sahni to Hsü, 20 February 1947, BSP \#164, Corr. Hsu, Jen, 32-33.
} 
Hsü required little further encouragement. After negotiating with his colleagues C.Y. Chang and Wu Zhengyi, he accepted Sahni's offer. By October 1948, he was back in Lucknow. This time, his wife and three young children accompanied him. ${ }^{89}$ Appointed a full professor and also the curator of the Institute's fledgling museum, he was thus present at the Institute's foundation stone laying ceremony on April 3, 1949..$^{90}$ Within a week Sahni was dead. ${ }^{91}$

Sahni's untimely passing left Hsü and other colleagues at the embryonic Institute in a challenging position. They shouldered the burden and soldiered on and, with the support of Sahni's widow, Savitri Sahni, pursued tasks that would establish the Institute on a firm footing. ${ }^{92}$ As the only full professor at the Institute, Hsü took on a leadership role. But he shied away from becoming the acting director, despite Savitri Sahni's desire that he take the job. Instead, T.M. Harris from the University of Reading was appointed an advisor from December 1949 to January 1950, and in May 1950, R.V. Sitholey was appointed as interim Director (office-in-charge). Hsü also helped bring O.A. Høeg of the University of Oslo to serve as Director from October 1951 to the beginning of August $1953 .^{93}$ With Sitholey, Hsü also helped organize and produce the first issue of the journal The Palaeobotanist (1952-). In 1950, the geologist D.N. Wadia (1883-1969) requested Hsü to take his place as the secretary of the section on Gondwana (冈瓦纳) at a three-day international geological conference. Hsü's summary of the session was subsequently published in the proceedings of the XIXth International Geological Congress, held in Algiers in 1952. ${ }^{94}$

In 1950, Hsü traveled abroad and represented the Institute in Sweden and England. ${ }^{95}$ He spent three months in Sweden and participated in the Seventh International Botanical Congress in Stockholm in July $1950 .{ }^{96}$ In addition to meeting with T.G. Halle and a host of other prominent botanists, he delivered two papers. ${ }^{97} \mathrm{He}$ also met the Swedish geographer and topographer Sven Hedin (1865-1952) and studied his research methods, especially his approach to note-taking and record maintenance. At the Swedish Museum, he visited Otto Gunnar Elias Erdtman's (1897-1973) Palynology Laboratory, where he saw samples of the Swedish Varve (a type of sedimentary rock) (Fig. 4).

Back in Lucknow, Hsü continued to conduct research, write, and teach. In August 1951 he accompanied a Mr. Bharadwaj on a trek through Laredura, Zewan, and Srinagar (all in Kashmir) to collect quaternary samples. ${ }^{98} \mathrm{He}$ also inherited from Sahni the Institute's first doctoral student, M.N. Bose

\footnotetext{
${ }^{89}$ Xu Ren, Personnel Dossier (个人档案), 31, 46. Zhang Yuzhen 张玉珍 (wife, 35), Xu Jinsheng 徐金声 (son, 10), Xu Mousheng 徐缪声 (daughter, 7), and Xu Zhusheng 徐竺声 (daughter, 4). In 2010, Hsü's youngest daughter, Xu Zhusheng, did a brief interview about her parents in which she described the family's life in India (Xu 2010).

${ }^{90}$ The stone was an especially constructed composite of different fossil specimens from all over the world, some as old as 60 million years and only discovered recently. India's Prime Minister Jawaharlal Nehru (1889-1964) did the honors. Also present was Shanti Swarup Bhatnagar (1894-1955), the Director-General of the (Indian) Council of Scientific and Industrial Research, who noted in his address that paleobotany had great importance for "economic geology as it would help scientists jn their investigations of mineral wealth of the country". "Role of Science in India: Pandit Nehru's Call," The Times of India; April 4, 1949, 5.

${ }^{91}$ Sahni died of a heart attack on the night of 9 April 1949. See: Gupta 1978, pp. 1-2; Sahni 1952, p. 8; "Late Dr Birbal Sahni," The Times of India, Apr 11, 1949, 7.

${ }^{92}$ Unless otherwise noted, the discussion here is drawn from (1) Hsü's memoir (Xu 2000b), in particular pp. 316-18; and (2) A supplementary explanation (补充说明) dated 30 November 1978 from his Personnel Dossier (个人档案), 8-12.

${ }^{93}$ Hsü recommended Ove Arbo Høeg (1898-1993) over the Dutchman Loreash [sic] because the former was a paleobotanist. On these appointments and the role of UNESCO, see also Anon n.d.

${ }^{94}$ I have not been able to verify this claim, not having been able to find a copy of the conference proceedings. As far as I can tell, Hsü did not travel to Algiers, which suggests that the conference Wadia requested him to attend was convened elsewhere.

${ }^{95}$ On this, see also Xu Ren, Personnel Dossier (个人档案), 5, 20. In one instance he also mentions visiting France (2-2)

${ }^{96}$ Held from 12 to 20 July 1950, the conference was attended by about 1250 botanists from 50 countries (Walsh 1950).

${ }^{97}$ Hsü's two papers were: (1) "New Information on Homoxylon rajmahalense SAHNI," Session 6 (Morphology and Phylogeny of Mesozoic Gymnosperms), 18 July, 2 to 3.50 pm (Attendance: 40); Chair: H.N. Andrews; and (2) "Devonian Spores from Yunnan, China," was part of Session 3 (11 July, 9 am to noon, Attendance: 70); Chair R. Potonie, Recorders: G. Erdtman and O. Hedberg. See: Osvald and Aberg 1953, pp. 583-584, 888.

${ }^{98}$ Locality Register, Birbal Sahni Institute of Palaeosciences, 1-2.
} 
Figure 4. Hsü in Musoorie, India, during the summer of 1950. Source: Xu 2000a.

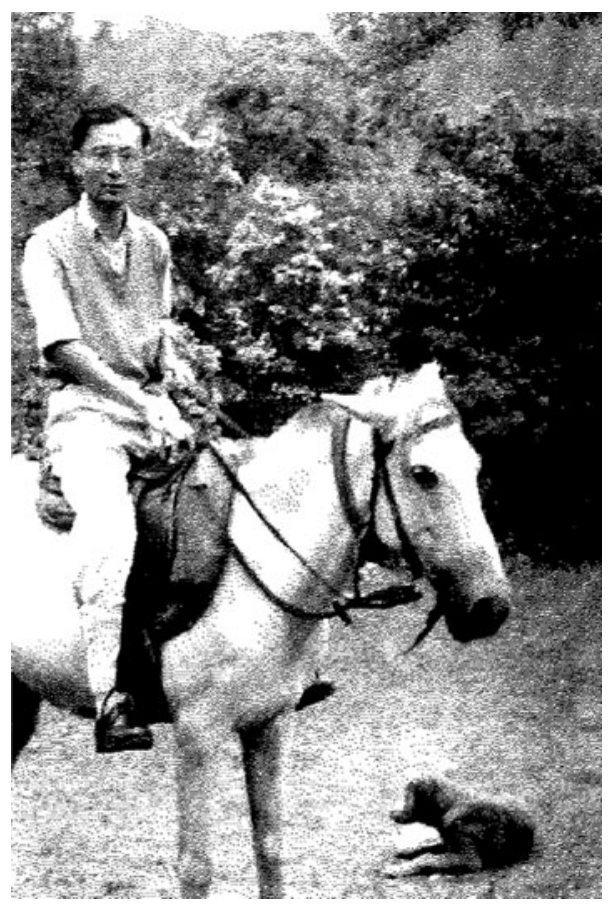

(1925-2011). With Bose, Hsü co-authored an essay for the Sahni Memorial Volume (Hsü and Bose 1952). ${ }^{99}$ More co-authored essays with Bose and other colleagues followed. ${ }^{100}$ Hsü regarded training Bose as his most important contribution to Indian paleobotany. Bose's own distinguished career culminated in the directorship of the Institute from 1980 to $1985 .{ }^{101}$ Hsü also took charge of the Institute's museum. The Institute's Annual Report for 1952-53 noted that "[m] uch preliminary work and planning of the museum had been done by Dr. Jen Hsu, but the final effort was left to Dr. K.R. Surange, who was given charge of the museum from 22 September 1952." 102

Throughout these years, a return to China was never far from Hsü's mind. He had originally negotiated a three-year leave with C. Y. Chang and Sun Yunzhu 孙云铸 (1895-1979), the respective heads of the departments of Botany and Geology at Peking University. But upon his arrival in Lucknow he had discovered that his appointment was a permanent one. ${ }^{103}$ It is possible that these considerations were on his mind when he turned down Savitri Sahni's offer of the Institute's directorship. During his time in Sweden in the summer of 1950, he discussed the matter with Halle, who encouraged him to

\footnotetext{
${ }^{99}$ As far as I can tell, Hsü never co-authored anything with Sahni although such a possibility had been raised in their correspondence: "It so happens that I have with me a half finished paper on some early Mesozoic plants from Miao-Tsaw and Yunnan-Fu which, if you like, we may complete together" (Sahni to Hsü, 18 November 1944, BSP \#164, Subj. File 60, 2). The closest they got is when Sahni edited and corrected Hsü's work and had it published: "Your paper on Devonian plant fragments has been printed in the M.O.P Iyengar Commemoration Volume, shortly to be issued. I have seen the proofs as carefully as possible...I have incorporated all corrections and criticisms made by your external examiners, and have inserted a line of thanks to them as coming from yourself” (Sahni to Hsü, 20 February 1947, BSP \#164, Corr. Hsu, Jen, 32). The paper was published as "Plant Fragments from Devonian Beds in Central Yunnan, China" (Hsü 1946).

${ }^{100}$ For example: (1) Hsü and Bose 1952; (2) Bose and Hsü 1953; and (3) Hsü and Dube 1952. These papers and talks were also listed in the 1952-53 Annual Report of the Birbal Sahni Institute of Paleobotany.

101“Past Heads of Institute," https://www.bsip.res.in/bsip_past_institute_heads.php (accessed 21 December 2020). For more on Bose, see Chandra 2013.

${ }^{102}$ Annual Report (1952-53), Birbal Sahni Institute of Paleobotany, 4.

103“补充说明,” 30 November 1978, Xu Ren, Personnel Dossier (个人档案), 9-10.
} 
return because he felt that materials in China were more plentiful than in India (Xu 2000b, p. 316). But Savitri Sahni was particularly keen that Hsü stay on in India, even take Indian citizenship if necessary. Hsü suspected that she had even enlisted Indian Prime Minister Jawaharlal Nehru in her charm offensive. During their meeting in 1951, Nehru advised Hsü to remain in India, explaining that China was unlikely to recover for another ten years; it was India that would have the greatest prestige in Asia. Hsü politely declined (Xu 2000b, p. 317). Much, of course, had changed in China since his departure. The Civil War had ended in 1949, the Nationalists had retreated to Taiwan, and the mainland was under Communist rule.

Global politics would also have their say. The Chinese annexation of Tibet that same year turned public opinion in India against China, souring some of Hsü's relationships and generating a sense of unease. When he met with the CAS delegation in New Delhi later that year, he was therefore especially susceptible to the pressure applied on him to return. Within a year he resigned his position at the Institute. Having left the Republic of China at the end of 1948, Hsü returned to the People's Republic of China in May 1952. ${ }^{104}$

\section{Transnational science in a time of Pan-Asianism}

The intersection of science, colonialism, and nationalism has been a significant theme in the historiographies of both China and India. Also dominant are frameworks that typically connect science in China and India to 'Western' science. ${ }^{105}$ And although we are no longer hostage to the kind of diffusion model proposed by George Basalla (1967), who theorized that modern science was a distinctly Western product that was subsequently transmitted unidirectionally everywhere else, the frameworks and themes noted above remain influential. Recently, scholars have begun to explore transnational networks from a variety of new perspectives, tracing overseas Chinese contributions to medical practice and policy in mainland China and Taiwan, Indian medical aid to China after 1937, and south-south Cold War scientific networks anchored in Asia (Anon. 2021; Framke 2017; Ghosh 2016; Soon 2020).

Consonant with these new approaches, Sahni and Hsü's story exemplifies two important forms of circulation - of scientists and of scientific materials - that can help us push beyond the dominant frameworks. But what propelled this relationship? We can certainly ascribe partial responsibility to that most banal of human frailties: ego. In 1942, Sahni had written to Panna Lall, "I am indeed proud that a scholar from China has expressed a desire to come and work in my laboratory."106 But linked to such personal concerns was an appreciation of the wider politics of the time, at both national and transnational scales. Among the products of the enthusiasm for Pan-Asianism during the first half of the twentieth century was interest among Chinese and Indian intellectuals for mutual rediscovery and for forging a united front against colonialism. ${ }^{107}$ Sahni and Hsü reflected the zeitgeist. In a letter to C.Y. Chang written a few months after Hsü's arrival in Lucknow, Sahni had stated, "I consider it a great privilege to be allowed to do anything towards reviving the cultural contacts of India with China, which are thousands of years old but have long been neglected." 108 According to Hsü, Sahni understood that he (Hsü) was a patriot and that everyone deeply hated foreign aggression. He wanted Hsü to join him and fight for the people of the Orient together (共同为东方人争气 gongtong wei dongfang ren zhengqi). ${ }^{109}$ Hsü recalled that he and Sahni were of like mind - the establishment of a Paleobotanical Institute in Lucknow following India's independence (achieved in 1947) would be a fitting reply to Europeans and Americans who deemed the people of the Orient incompetent (认为东方人不行 renwei dongfangren bu xing; Xu 2000b: 315-16). Sahni and Hsü were, of

\footnotetext{
${ }^{104} \mathrm{Xu}$ Ren, Personnel Dossier (个人档案), 2-1.

${ }^{105}$ This literature is too large to cite comprehensively, but exemplary are Shen 2014; Wang 2007; Lei 2014; Mukharji 2009; Nandy 1995; Phalkey 2013; and Lightman et al 2013.

${ }^{106}$ Sahni to Panna Lall, 23 December 1942, BSP \#164, Subj. File 60, 12 and 18.

${ }^{107} \mathrm{~A}$ useful and comprehensive primer for scholarship on China and India is Sen 2021.

${ }^{108}$ Sahni to Chang, 2 July 1944, BSP \#164, Subj. File 60, 96.

${ }^{109}$ Supplementary Explanation (补充说明), 30 November 1978, Xu Ren Personnel Dossier (个人档案), 10.
} 
course, not alone in sharing these sentiments. In a July 1943 letter to Tsinghua University President Mei Yiqi (梅貽琦 Yi-chi Mei), the mathematician Shiing-shen Chern, recalling his recent sojourn in Calcutta, observed that the conditions for research at the University of Calcutta were "as good as in England and America." Chern further noted that Indians desired exchanges with China as Sino-Indian and not as Sino-British interactions. He recommended that Chinese scientists should try to stay in India for longer periods to help improve bilateral relations. ${ }^{110}$

Such a desire to connect science and scientists across Asia was not always evident at more formal levels. Following the end of the Second World War, new forms of contestation arose over the idea of Asia and the ideal of Asian solidarity jostled uncomfortably with realities of a fast-decolonizing world and the articulation of new national interests. Much of this was exemplified at the March 1947 Asian Relations Conference, where China and India presented competing visions of their historical zones of cultural influence. ${ }^{111}$ Even as political ideas of Asia were being refashioned, and despite a fair amount of discussion about the importance of Science, there was little participation by Chinese or Indian scientists: of India's 57 delegates and observers, only four were scientists; of China's nine delegates and observers, not a single one was a scientist. ${ }^{112}$

Distanced from such elite-level politics, Sahni and Hsü's collaboration and research point to heretofore neglected facets of the history of science in Asia. In particular, their research into the native habitats of two types of Permian plants had implications for the theory of Continental Drift. ${ }^{113}$ In some of his early research, Sahni had compared and correlated Indian fossil flora with those found in the Southern Hemisphere. A focus of this work was the plant Glossopteris (a type of seed fern), which typically needed cold temperate conditions to thrive (Sahni 1935a). That its fossils were found in regions as diverse as India, South Africa, Australia, South America, and Antarctica posed an interesting puzzle, suggesting that these regions had once belonged to a larger landmass. In 1927, T.G. Halle discovered in the Chinese province of Shanxi a different type of large flora, called Gigantopteris (Wang 1999). This plant grew under moist tropical conditions and soon there was evidence that its habitat extended south into Central Sumatra. These findings suggested that the Himalayas were the physical embodiment of a geological process that had reshaped continents. Shakti M. Gupta in her biography of Sahni explains:

This floristic contrast is so striking as by itself to raise the suspicion that the two floras, one essentially northern, the other southern, must have lived in different climates. Indeed, the current view is that the Glossopteris flora was probably evolved in a temperate climate on a continent just emerged from glaciation, the Gigantopteris flora in a warmer climate analogous to that of the European coal measures. (Gupta 1978, p. 45)

Sahni thus came to believe "that the peninsula of India had once been part of an old continental block, Pangea, which had broken up, and that the Indian part had drifted into close proximity with the land mass forming the main Asiatic continent (Proc. 24th Indian Sci. Congr., Hyderabad, 1937, pp. 502-506)" (Hamshaw 1950, pp. 270-271; Sahni 1935b; Sahni 1937) (Fig. 5).

It is therefore not surprising that Hsü decided to devote one chapter of his thesis to specimens of Gigantopteris flora that had been collected in northeastern Yunnan, nor that Sahni was so interested in

\footnotetext{
${ }^{110}$ S. S. Chern to President Mei Yiqi of Tsinghua, August 25, 1943, in Research Office on the History of Tsinghua University 1994, pp. 307-316, see p. 309. My thanks to Zuoyue Wang for alerting me to this resource episode.

${ }^{111}$ On the uneven legacy of the Asian Relations Conference, see Mansergh 1947; Thakur 2019; and Stolte 2014.

${ }^{112}$ The Indian scientists were S.S. Bhatnagar, D.R. Gagdil, C.V. Raman, V.K.R.V. Rao. The Conference had participation from 28 countries (the US, UK, USSR, and Australia attended as observers) who supplied a total of 243 observers and delegates (Asian Relations Conference 1948). In some ways this echoes the post-May $4^{\text {th }}$ excitement for Science among intellectuals in China, who were for the most part cultural and literary figures. The involvement of scientists is less clear.

${ }^{113}$ Proposed by the German geophysicist Alfred Wegener (1880-1930) in 1912, the theory of Continental Drift - itself a precursor to Plate Tectonics - was controversial and far from universally accepted during the first half of the twentieth century. For more on this history, see Oreskes 1999; for more on some of latest research on the speed of the collision between the Indian microcontinent and Eurasia, see Andrews 2021.
} 
(a)

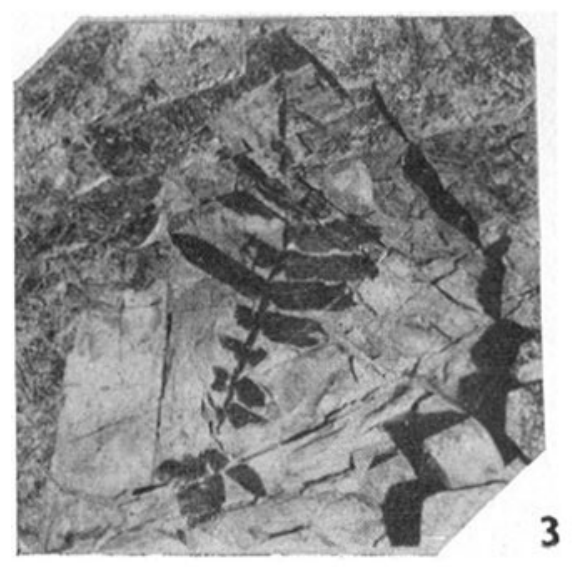

(b)

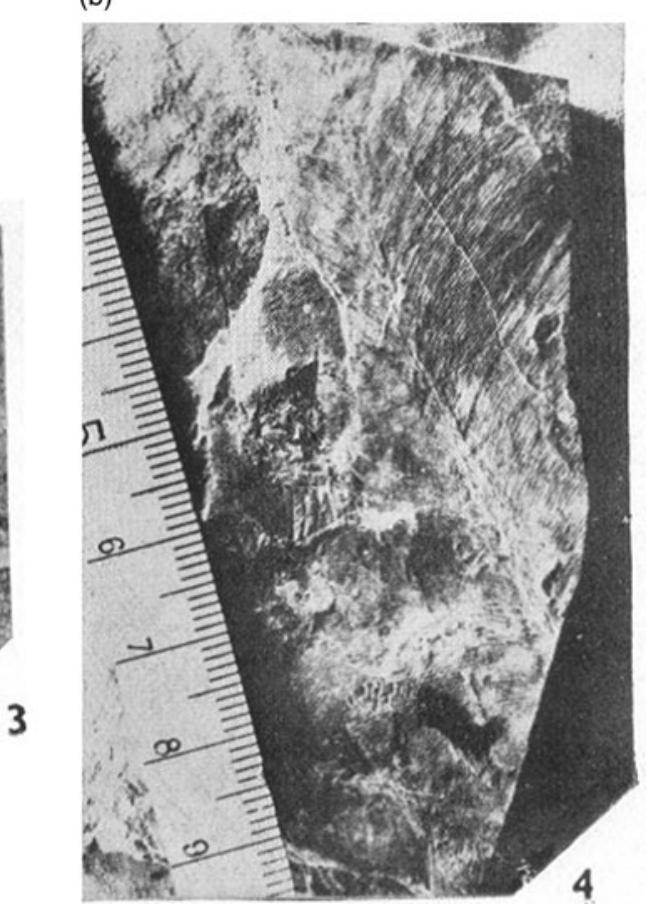

Figure 5. (a) Gigantolloclea guizhouensis from Hsianwei Group, Shuanghu, Northern Tibet, China. Upper Permian. (b) Glossopteris communis from Qubu Formation, Kujian, Southern Tibet, Upper Permian.

Source: Hsü 1978, p. 143 (Plate 1) and p. 145 (Plate 3).

his analysis. In his evaluation of the thesis, Sahni wrote, "The fifth and last paper describes a collection of plants belonging to the Gigantopteris flora in Yunnan, among which five new species have been recognized. Geographically as well as in its composition the flora serves as a link between the typical Gigantopteris flora of China and Korea on the one side and that of Sumatra on the other" (emphasis in original). ${ }^{114}$ Halle too was impressed by Hsü's chapter, commenting that "[p]erhaps the most interesting result of Mr. Hsu's work is that the Huitseh flora is shown to be entirely different from the Indian Gondwana flora [referring to glossopteris]. Since the discovery of the Huitseh flora extends the distribution of the East Asiatic Cathaysia flora yet farther towards the west, this fact enhanced the extraordinary difficulty of explaining the contrast between two floras which are so near in space, and coincide or at least overlap in time."115 (Fig. 6)

Hsü would revisit these questions in writings later in his career. In 1976, he published on the discovery of glossopteris flora in southern Tibet in Dizhi kexue (Scientia Geologica Sinica), noting that:

The Qubu Formation is widely distributed in a belt about $50 \mathrm{~km}$ north to the main Himalayas, from Longda, Selong, Tulong, Qubu to Quzong, that indicates that the Himalayan region was then the interior part of the [sic] Gondwanaland. Thus, it disproves the so-called "Himalayan Geoscyncline" and the geosuture line between the Indian Plate and the Eurasia Plate. (Hsü 1976)

\footnotetext{
114“Report of the Internal Examiner on the Thesis by Mr. Jen Hsü for the degree of Ph.D. at Lucknow," 20 May 1946, BSP \#164, Corr. Hsu, Jen, 35-37 (quote on 36).

${ }^{115}$ Halle, "Report on Mr. Jen Hsü's thesis for the degree of Doctor of Philosophy.” BSP \#164, Corr. Hsu, Jen, 45.
} 


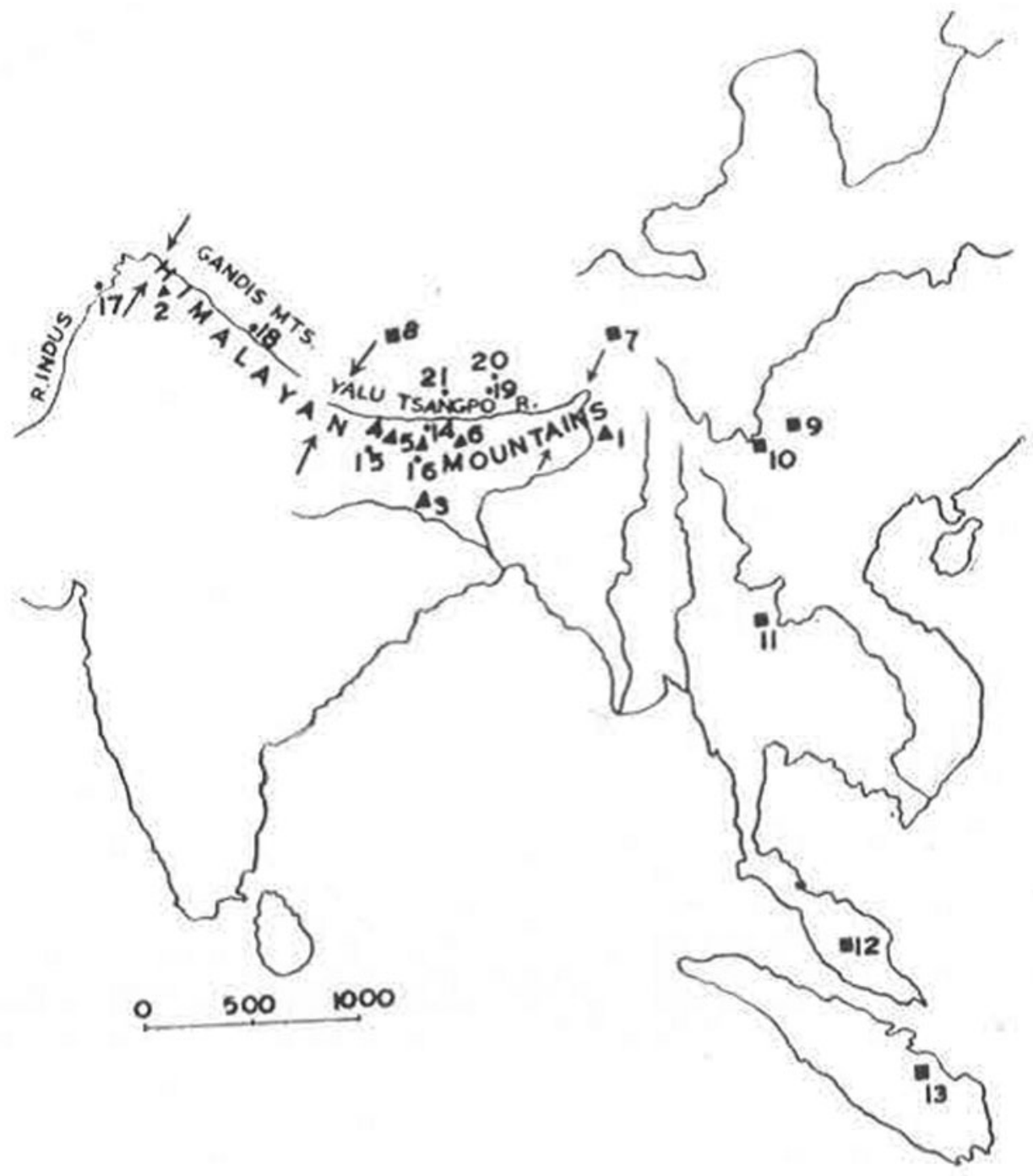

Figure 6. MAP 1 - Fossil localities mentioned in Hsü's paper. - Cathaysia flora; Glossopteris flora; arrows indicating the direction of crustal movement of the India plate and the Eurasia plate.

Source: Hsü 1978, p. 135.

Two years later, he wrote another paper drawing upon his research in the same region, concluding that,

The recent discovery of the Glossopteris flora from the Qubu Formation of Southern Tibet and the Gigantopteris flora from Shuanghu of Northern Tibet shows no relationship with each other. This strongly supports the view of Continental drift that the India block drifted in Cretaceous from the south-eastern corner of Africa and later on in Eocene joined up with Asia to become its subcontinent. (Hsü 1978) (See Fig. 6)

By exploding the temporality and spatial character of both Asia and modern nation states, Hsü and Sahni's research made a mockery of nationalism and human-scale history. Two interpretations are possible here. On the one hand, their activities expand how we might think about a practice of 
Pan-Asianism that was driven by research questions and centered on the circulation and exchange of knowledge, expertise, and scientific specimens. On the other hand, they also point to the limitations of the term itself, which should be seen as problematic not just for the various kinds of political and cultural power projection it enabled, whether initially by Japan or later by China and India, but also for restricting a broader understanding of twentieth-century inter-Asian history (Sen and Tsui 2021).

\section{Conclusion}

Hsü's association with Sahni and his time in India would render him continuously suspect in the eyes of the Chinese state and Communist Party. ${ }^{116}$ Shortly after his return to Beijing in the summer of 1952, he underwent thought reform. He admitted - almost pro forma - that he had adopted the thinking of a comprador (maiban 买办), valorizing a purely technical view on things (chun jishu guandian 纯技术观点, i.e., he had ignored politics). He acknowledged he had come under the spell of Sahni and Halle and adopted their international outlook. As a result, he had become detached from reality. ${ }^{117}$ The official verdict on his thought reform would list shortcomings and strengths (in that order): Hsü suffered from an ambivalent nature, especially as it applied to ideology. He cherished too much a good reputation, could not tolerate much hardship, and lacked focus because of too many interests. On the other hand, he was enthusiastic about work and had great patience. He was receptive to criticism and advice, friendly, and happy to help those in need. ${ }^{118}$

Although the matter-of-fact admission - detached from reality - is a commonplace CCP thought reform “formulation" ( $t$ ifa 提法), in the case of Hsü it forces an altogether different reckoning, one between "reality" as defined by the nation, and "reality" as grasped from the perspective of the earth (Schoenhals 1992). In unexpected ways, Hsü's "thought reform" thus reveals how within the logic of the nation state, engaging the scale of the earth necessarily became a kind of "detachment," for to think geologically, one could not but confront the utter insignificance and arbitrariness of the nation and human existence itself (Bjornerud 2018).

Some fourteen years later, Hsü's international connections would remain a political handicap. A career-sketch drafted in 1966 observed that although there was no evidence of his having joined reactionary groups, he did have complicated relations with people abroad. Particularly noteworthy in this regard were his communications in 1954 with scholars in India, Sweden, and the US. ${ }^{119}$ Further, during Mrs. Sahni's visit to the PRC in 1958, he had gone to receive her without permission and even gifted to her academic literature and fossil samples. Within a few weeks of the drafting of the career-sketch, China was engulfed in the Great Proletarian Cultural Revolution (1966-1976). To protect himself and his family, Hsü destroyed a signed copy of Nehru's autobiography. ${ }^{120}$ In spite of such difficulties, Hsü continued to send offprints of his articles to the Sahni Institute well into the 1980s, invariably inserting friendly hand-written annotations. ${ }^{121}$ As a fitting tribute to his legacy, starting in 2003 some of his Chinese students retraced his steps in Southwestern China and Northern India (Li, Wang, and Yao 2007).

\footnotetext{
${ }^{116}$ On the experiences of scientists educated in the West who returned to China during the early PRC, see Wang 2018. It is also worth reflecting for a moment what Hsü's fate might have been had he stayed on in India. After the 1962 war, thousands of Chinese-Indians were rounded up from Calcutta, Bombay, Makum, Kalimpong, and other cities and transported to internment camps at Deoli in Rajasthan. The fate of two other Chinese nationals suggests the spectrum of possible outcomes that Hsü may have confronted. The artist Chang Xiufeng, who had arrived in India in 1947, became a target of the state even before the conflict of 1962. He was jailed on multiple occasions and eventually forced to leave the country. The scholar and Indologist Xu Fancheng, on the other hand, famous for translating many important classical works from Sanskrit into Chinese, was relatively unscathed during his three-decade stay from 1945-1975 at the Aurobindo Ashram in Pondicherry. On Chang, Sen 2018, pp. 417-430; on Xu: Ashok 2019.

117“中国科学院宁区思想改造学习总结,” 3 September 1952, Xu Ren Personnel File (个人档案), 2-2.

118“思想改造学习总结登记表(丁表),” 17 September 1952, Xu Ren Personnel File (个人档案), 35/36.

119“干部简历表,” 14 April 1966, Xu Ren Personnel File (个人档案), 39.

“干部简历表,” 14 April 1966, Xu Ren Personnel File (个人档案), 40.

120“1946 见到了尼赫鲁, 他送给我一本自传, 并有他的签名. 后在文革中被自己销毁了 (Xu 2000b, p. 316).”

121“To Birbal Sahni Institute of Palaeobotany, with best wishes to all palaeobotanical friends, from J. Hsü, April 15, 1977.”
} 
The story of Sahni and Hsü offers us new perspectives on the connected histories of science across China and India and should spur us to recover and reassess other accounts of inter-Asian scientific connections. Although news tickers today are dominated by stories of tense geopolitical machinations, instances of China-India scientific cooperation and collaboration nonetheless persist. Much as in the case of Sahni and Hsü, the object of such research sometimes transcends contemporary politics (Lewis and Songster 2016). On occasion, it also transcends the earth, shifting our collective gaze toward the firmament. Near Pangong Lake, which straddles the Line of Actual Control between China and India, both countries have established telescope stations to observe and record solar flares, supernova, and other events in space. Since 2014, scholars have traveled back and forth and co-authored papers. Plans are now afoot to jointly construct a Thirty-Metre Telescope, which when complete will be three times larger than its nearest equivalent in Hawaii (Karnad and Tikkoo 2020).

Acknowledgments. I would like to thank the editors of this special issue, Adhira Mangalagiri and Tansen Sen, as well as the two anonymous reviewers for their incisive and thorough feedback on earlier drafts of this article. Jiang Lijing, Wang Zuoyue, Emma Rothschild, Bill Kirby, and Partha Ghosh generously read or discussed various versions. Chen Yuqian provided expert research assistance. A special word of thanks to Li Ang at the Institute for the History of Natural Sciences at the Chinese Academy of Sciences in Beijing and to Mukund Sharma at the Birbal Sahni Institute of Palaeosciences in Lucknow. For their incisive comments and questions, my grateful thanks also to audience members at Haverford College, Fudan University, Christ University (Bangalore), the Asia Research Institute (ARI; National University of Singapore), and Heidelberg University. A two-week fellowship at ARI in the fall of 2019 allowed me to begin work on a preliminary draft. My thanks to Anthony Medrano, Stefan Hübner, and Tim Bunnell for hosting me and making me feel so welcome. Research for the article was supported by an SSRC Transregional Research Junior Scholar Fellowship (InterAsian Contexts and Connections).

\section{References}

\section{Archives and Libraries}

Nehru Memorial Museum and Library, New Delhi

Birbal Sahni Institute of Paleosciences, Lucknow

Tagore Library, University of Lucknow

Institute for the History of Natural Science, Chinese Academy of Science, Beijing

\section{Newspapers}

Times of India

Renmin ribao

\section{Websites}

https://www.bsip.res.in

http://flora.huh.harvard.edu

https://stratigraphy.org

\section{Books and Articles}

Andrews, Robin George. (2021). “The New Historian of the Smash that Made the Himalayas.” Quanta Magazine, 14 April 2021. (accessed 15 April 2021).

Anon. (n.d.). History. Birbal Sahni Institute of Palaeosciences, website. Available at: https://www.bsip.res.in/bsip_institute_ history.php (accessed 21 December 2020).

Anon. (1930). “The Fifth International Botanical Congress.” Nature 126, pp. 406-07.

Anon. (2012). “张景钱 (Zhang Jingyue).” In Ershi shiji Zhongguo zhiming kexuejia xueshu chengjiu gailan, di yi fenci, shengwuxue juan 20世纪中国知名科学家学术成就概览, 第一分册.生物学卷 (An Overview of the Academic 
Achievements of Famous Chinese Scientists in the Twentieth Century, Vol. 1 Biology), edited by Qian Weichang 钱伟长, pp. 95-101. Beijing: Kexue chubanshe.

Anon. (2016). "Dedicated to 100 Years of Wu Zhengyi." Plant Diversity 38: 6 (December), pp. 259-344.

Anon. (2021). "What Does South-to-South Mean for Cold War Science and Technology in Asia." Conference at the Max Planck Institute for the History of Science, 10 May 2021. (accessed 11 May 2021).

Ashok, Sowmiya (2019). "From Santiniketan to Peking University: Artist's decades-old paintings trace India-China links." The Indian Express 26 November 2019. Available at: https://indianexpress.com/article/india/from-santiniketan-topeking-university-artists-decades-old-paintings-trace-india-china-links-6136867/ (accessed 30 December 2020).

Asian Relations Conference. (1948). Asian Relations, Being Report of the Proceedings and Documentation of the First Asian Relations Conference, New Delhi, March-April, 1947. New Delhi: Asian Relations Organization.

Basalla, George (1967). “The Spread of Western Science. A Three-Stage Model Describes the introduction of Modern Science Into Any Non-European Nation.” Science (New York, N.Y.) 156:3775, pp. 611-22.

Bjornerud, Marcia (2018). Timefulness: How Thinking Like A Geologist can Help Save the World. Princeton: Princeton University Press.

Bose, M. N. and J. Hsü (1953). "On Some Coniferous Cones, Probably of Brachyphyllum, from the Jurassic of the Rajmahal Hills, Bihar, India." In Proceedings of the National Institute of Sciences of India 19, 2: pp. 203-09.

Burra, Neera (ed.) (2017). A Memoir of Pre-Partition Punjab, Ruchi Ram Sahni, 1863-1948. New Delhi: Oxford University Press.

Cao, Yin. (2018). From Policemen to Revolutionaries: A Sikh Diaspora in Global Shanghai. Leiden: Brill.

Chakrabarty, Dipesh ([2000] 2007). Provincializing Europe: Postcolonial Thought and Historical Difference. Princeton, NJ: Princeton University Press.

Chandra, Anil (2013). “Mahendra Nath Bose (3 March 1935-27 April 2011).” Biographical Memoirs of Fellows of the Indian National Science Academy 40: pp. 37-55.

Cohen, Paul A. ([1984] 2010). Discovering History in China: American Historical Writing on the Recent Chinese Past, with a New Introduction by the Author. New York: Columbia University Press.

Committee on Scholarly Communication with the People's Republic of China (U.S.) (1983). China Exchange News, Volumes 11-13. Washington, D.C.: Committee on Scholarly Communication with China.

Duara, Prasenjit (1995). Rescuing History From the Nation: Questioning Narratives of Modern China. Chicago: University of Chicago Press.

Duara, Prasenjit (2010). “Civilization and Realpolitik.” In India China: Neighbors Strangers, ed. Ira Pande, pp. 20-33. New Delhi: Harper Collins.

Duara, Prasenjit (2015). The Crisis of Global Modernity - Asian Traditions and a Sustainable Future. Cambridge: Cambridge University Press.

Fan, fa-ti (2004). British Naturalists in Qing China: Science, Empire, and Cultural Encounter. Cambridge, MA: Harvard University Press.

Fiskesjö, Magnus (2011). “Science Across Borders: Johan Gunnar Andersson and Ding Wenjiang." In Explorers and Scientists in China's Borderlands, 1880-1950, eds. Stevan Harrell, Charles McKhann, Margaret Swain and Denise M. Glover, pp. 240-66. Seattle: University of Washington Press.

Framke, Maria (2017). "We Must Send a Gift Worthy of India and the Congress!' War and Political Humanitarianism in Late Colonial South Asia.” Modern Asian Studies 51:6, pp. 1969-98.

Ge, Mingde 葛明德 (1997). “张景钱 (Zhang Jingyue)”. In Zhongguo xiandai kexuejia zhuanji 中国现代科学家传记 (Biographies of Modern Chinese Scientists), edited by Anon., pp. 490-94. Beijing: Kexue chubanshe.

Ghosh, Arunabh (2016). “Accepting Difference, Seeking Common Ground: Sino-Indian Statistical Exchanges 1951-1959.” BJHS Themes, 1, pp. 61-82.

Ghosh, Arunabh (2017). “Before 1962: The Case for 1950s China-India History.” The Journal of Asian Studies 76:3, pp. 697-727.

Gordin, Michael D. (2015). Scientific Babel: How Science was Done Before and After Global English. Chicago: University of Chicago Press.

Gordin, Michael D. (2021). “Anti-Anti-Anti-Science.” Los Angeles Review of Books, April 20, 2021 (accessed 10 May 2021 ).

Gupta, Shakti M. (1978). Birbal Sahni. New Delhi: National Book Trust, India.

Haas, William J. (1988). "Botany in Republican China." In Science and Medicine in Twentieth-Century China: Research and Education, eds. John Z. Bowers, J. William Hess, and Nathan Sivin, Volume 3, pp. 31-64. Ann Arbor: University of Michigan Press.

Hamshaw, Thomas H. (1950). "Birbal Sahni." Obituary Notices of Fellows of the Royal Society 7:19, pp. 265-77.

Harper, Tim and Sunil S. Amrith (2012). "Sites of Asian Interaction: An Introduction." Modern Asian Studies 46:2, pp. $249-57$.

Ho, Engseng (2017). "Inter-Asian Concepts for Mobile Societies.” Journal of Asian Studies 76:4: pp. 907-28.

Hsü, Jen (1946). "Plant Fragments From Devonian Beds in Central Yunnan, China.” In M.O.P. Iyengar Commemoration Volume, Journal of the Indian Botanical Society, eds. Birbal Sahni, M. O. P. Iyengar and the Indian Botanical Society, pp. 339-60. Bangalore: Bangalore Press.

Hsü, Jen (1976). “Zangnan shiyangchi zhiwuqun de faxian he qi zai dizhixue ji gu dilixue shang de yiyi 藏南舌羊齿植物群的 发现和其在地质学及古地理学上的意义 (On the Discovery of a Glossopteris Flora in Southern Xizang and its Significance in Geology and Palaeogeography).” Dizhi kexue 地质科学 (Scientia Geologica Sinica), 4: October, pp. 323-331+IV. 
Hsü, Jen (1978). “On the Palaeobotanical Evidence for Continental Drift and Himalayan Uplift.” The Palaeobotanist 25, pp. 131-45. [Reprinted (without plates) in Xu Ren zhuzuo xuanji, 237-252; also republished in Chinese in 1981.

Hsü, J. and M. N. Bose (1952). "Further Information on Homoxylon Rajmahalense Sahni." Journal of the Indian Botanical Society 32:1 \& 2, pp. 1-12.

Hsü, J. and S. N. Dube (1952). "Preliminary Studies on the Quarternary Deposits of the Kashmir Valley." Lecture at the Institute of Paleobotany, Lucknow, 16 April 1952.

Hsü, Jen, R.N. Lakhanpal, T.S. Mahabale, S.R. Narayana Rao, R.V. Sitholey and K.R. Surange (eds.) (1952). Palaeobotanist: Vol. 1 - Birbal Sahni Memorial Volume. Lucknow: Birbal Sahni Institute of Palaeobotany.

Huang, Rui-Lan (2016). "Prof. Huan-Yong Chen: A Leading Botanist and Taxonomist, One of the Pioneers and Founders of Modern Plant Taxonomy in China.” Protein \& Cell 7:11, pp. 773-76.

Karnad, Raghu and Anmol Tikkoo (2020). “The Clear Night Sky Over India and China's Hostile Border.” New Yorker 19 September 2020. Available at: https://www.newyorker.com/news/dispatch/the-clear-night-sky-over-india-and-chinashostile-border (accessed 20 September 2020).

Kingsberg Kadia, Miriam (2019). Into the Field: Human Scientists of Transwar Japan. Stanford: Stanford University Press.

Lei, Sean Hsiang-lin (2014). Neither Donkey nor Horse: Medicine in the Struggle Over China's Modernity. Chicago: University of Chicago Press.

Lewis, Michael and Elena Songster (2016). Studying the Snow Leopard: Reconceptualizing Conservation Across the China-India Border. BJHS Themes 1: pp. 169-98.

Li, Chengsen 李承森 (1993). “Huainian wo de daoshi Xu Ren jiaoshou 怀念我的导师徐仁教授 (Remembering my Advisor, Professor Xu Ren).” Zhiwu zazhi 植物杂志 (Journal of Botany) 03:June, pp. 39-41.

Li, Chengsen 李承森, Wang Yufei 王宇飞 and Yao Yifeng 姚轶峰 (2007). “Yindu Dajiling - tongshang Ximalaya shan de 印度大吉岭 - 通向喜马拉雅山的驿站 (Darjeeling, India - A Station in the Himalayas).” Da ziran 大自然 3, pp. 34-36.

Li, Xingxue 李星学. (1991). “Guzhiwu xue fazhan jianzhi yu zhongguo guzhiwu xue fazhan gaikuang 古植物学发展简史与 中国古植物学发展概况 (A brief history of the development of paleobotany and an overview of its development in China).” Da ziran tansuo 大自然探索 (Exploration of Nature) 10, Sum. No. 36 (No. 2, 1991): pp. 93-99.

Lightman, Bernard V., Gordon McOuat and Larry Stewart (eds.) (2013). The Circulation of Knowledge Between Britain, India and China: The Early-Modern World to the Twentieth Century. Leiden; Boston: Brill.

Liu, Andrew B. (2020). Tea War: A History of Capitalism in China and India. New Haven: Yale University Press.

Mansergh, Nicholas Mansergh (1947). “The Asian Conference.” International Affairs 23: 3 (July), pp. 295-306.

Mukharji, Projit (2009). Nationalizing the Body: The Market, Print and Daktari Medicine in Colonial Bengal, 1860-1930. London: Anthem Press.

Mullaney, Thomas S. (2011). Coming to Terms with the Nation: Ethnic Classification in Modern China. Berkeley: University of California Press.

Nandy, Ashish (1995). Alternative Sciences: Creativity and Authenticity in two Indian Scientists. Delhi: Oxford University Press.

Oreskes, Naomi (1999). The Rejection of Continental Drift. Oxford: Oxford University Press.

Osvald, Hugo and Ewert Aberg (eds.) (1953). Proceedings of the Seventh International Botanical Congress, Stockholm, 12-20 July 1950. Stockholm: Almquist and Wiksell.

Phalkey, Jahnavi. (2013). Atomic State: Big Science in Twentieth-Century India. New Delhi: Permanent Black.

Phalkey, Jahnavi and Tong Lam (eds.) (2016). Science of Giants: China and India in the Twentieth Century. BJHS Themes 1, pp. 1-266.

Raj, Kapil (2007). Relocating Modern Science: Circulation and the Construction of Knowledge in South Asia and Europe, 1650-1900. London: Palgrave MacMillan.

Research Office on the History of Tsinghua University 清华大学校史研究室 (ed.) (1994). Qinghua Daxue shiliao xuanbian 清华大学史料选编 (Selected Materials Related to the History of Tsinghua University]) Vol. 3, Part 1. Beijing: Tsinghua University Press.

Saaler, Sven and Christopher W. A. Szpilman (eds.) (2011). Pan-Asianism - A Documentary History, Volumes 1 and 2. Lanham: Rowman \& Littlefield Publishers.

Sahni, Birbal (1935a). "The Glossopteris Flora in India." Proceedings of the 6th International Botanical Congress Amsterdam 2:1935, pp. 245-48.

Sahni, Birbal (1935b). “The Relations of the Indian Gondwana Flora With Those of Siberia and China." Proceedings of the 2nd Congress, of Carboniferous Stratig. Heerlen, Holland. Compte Rendu 1:1935, pp. 517-18.

Sahni, Birbal (1937). Wegener's Theory or Continental Drift With Reference to India and Adjacent Countries (General Discussion). Proceedings of the 24th Indian Science Congress, Hyderabad 1937, pp. 502-06.

Sahni, Birbal and M. O. P. Iyengar and the Indian Botanical Society (1946). M.O.P. Iyengar Commemoration Volume, Journal of the Indian Botanical Society. Bangalore: Bangalore Press.

Sahni, M. R. (1952). Birbal Sahni: A Biographical Sketch of his Personal Life. Palaeobotanist: Vol. 1 - Birbal Sahni Memorial Volume 1952, pp. 1-8.

Schaffer, Simon, Lissa Roberts, Kapil Raj and James DelBourgo (eds.) (2009). The Brokered World: Go-Betweens and Global Intelligence, 1770-1820. Uppsala: Uppsala Studies in History of Science, p. 35. 
Schmalzer, Sigrid (2016). Red Revolution, Green Revolution: Scientific Farming in Socialist China. Chicago: University of Chicago Press.

Schoenhals, Michael (1992). Doing Things With Words in Chinese Politics: Five Studies. Berkeley: University of California at Berkeley, Center for Chinese Studies, Research Monograph No. 41.

Sen, Tansen (2018). India, China, and the World: A Connected History. Lanham: Rowman \& Littlefield Publishers.

Sen, Tansen (2021). “The Emergence, Development, and Current State of China-India Studies." Journal of Asian Studies First View Published online 05 January 2021: pp. 1-25.

Sen, Tansen and Brian Tsui (eds.) (2021). Beyond Pan-Asianism: Connecting China and India, 1840s-1960s. New Delhi: Oxford University Press.

Seth, Suman (2017). "Colonial History and Postcolonial Science Studies." Radical History Review 2017:127, pp. 63-85.

Sharma, Mukund (2010). Prof. Birbal Sahni aur Pura-Vanaspati-Vigyan Sansthan, Lucknow (Birbal Sahni and the Institute of Paleobotany, Lucknow). Lucknow: Hindi Vangamaya Nidhi.

Shen, Grace (2014). Unearthing the Nation: Modern Geology and Nationalism in Republican China. Chicago: University of Chicago Press.

Soon, Wayne (2020). Global Medicine in China: A Diasporic History. Stanford: Stanford University Press.

Star, Susan Leigh and James R. Griesemer (1989). "Institutional Ecology, 'Translations' and Boundary Objects: Amateurs and Professionals in Berkeley's Museum of Vertebrate Zoology, 1907-39." Social Studies of Science 19:3, pp. 387-420.

Stolte, Carolien (2012). “Enough of the Great Napoleons!' Raja Mahendra Pratap's Pan-Asian Projects (1929-1939).” Modern Asian Studies 46:2, pp. 403-23.

Stolte, Carolien (2014). “The Asiatic Hour': New Perspectives on the Asian Relations Conference, New Delhi, 1947.” In The Non-Aligned Movement and the Cold War, eds. Natasa Miskovic, Natasa, Harald Fischer-Tiné and Nada Boskovska, pp. 75-93. London: Routledge.

Sun, Qigao 孙启高 (2009). “Gu zhiwuxue de gushi (5): Xu Ren yu Zhongguo zhiwuxue de xingqi 古植物学的故事 (5): 徐 仁与中国古植物学的兴起 (The story of paleobotany (5): Xu Ren and the rise of paleobotany in China).” Blog entry “livingfossil 的个人博客," 29 August 2009. Available at: http://blog.sciencenet.cn/home.php? $\mathrm{mod}=$ space\&uid = 225931\&do = blog\&quickforward = 1\&id = 252212 (accessed December 19, 2020).

Tagliacozzo, Eric, Helen F. Siu and Peter C. Perdue (eds.) (2015). Asia Inside Out: Changing Times. Cambridge, MA: Harvard University Press.

Thakur, Vineet (2019). “An Asian Drama: The Asian Relations Conference, 1947.” The International History Review 41: 3, pp. 673-95.

Tsui, Brian (2015). “Decolonization and Revolution: Debating Gandhism in Republican China.” Modern China 41:1, pp. 59-89.

Twenhofel, W. H. and R. R. Shrock (1935). "Invertebr. Paleontol. i.1, 1935.” Oxford English Dictionary Online.

Walsh, Lydia Bowme (1950). "Report of the Seventh International Botanical Congress." The American Biology Teacher 12:8 (December 1950), pp. 179-83.

Wang, Ning (2018). "Bowing to Chairman Mao: Western-Trained Intellectuals and the State in the Early PRC." Journal of Contemporary China 27:110, pp. 312-26.

Wang, Zi-Qiang (1999). “Giagantonoclea: An Enigmatic Permian Plant From North China.” Palaeontology 42:2, pp. 329-73.

Wang, Zuoyue (2007). “Science and State in Modern China.” Isis 98, pp. 558-70.

Wang, Zuoyue 王作跃 and Guo Jinhai 郭金海 (2019). “Transnational Mathematics and Movements: Shiing Shen Chern, Hua Luogeng, and the Princeton Institute for Advanced Study From World War II to the Cold War." Chinese Annals of History of Science and Technology 3:2, pp. 118-65.

Wu, Zhengyi 吴征镒 (1992). “Wu Zhengyi xiansheng fangtan lu 吴征镒先生访谈录 (Interview with Mr. Wu Zhengyi).” Yuanshi ziliao yu yanjiu 院史资料与研究 (Data and Research on the History of the Academy), 1992:3, pp. 1-15.

Xu, Ren (2000a). Xu Ren zhuzuo xuanji 徐仁著作选集 (Selected Works of Xu Ren). Beijing: Dizhi chubanshe.

Xu, Ren (2000b). “Xu Ren Huiyilu 徐仁回忆录 (Xu Ren Memoir)”. In Xu Ren zhuzuo xuanji 徐仁著作选集 (Selected Works of Xu Ren), ed. Ren Xu, pp. 313-19. Beijing: Dizhi chubanshe.

Xu, Zhusheng 徐䇥声 (2010). “Gu zhiwuxue de gushi (71): Yiwei gu zhiwu xuejia de nu'er dui fumu de huiyi 古植物学的故 事(7): 一位古植物学家的女儿对父母的回忆 (The story of paleobotany (71): the daughter of a paleobotanist remembers her parents).” Blog entry “livingfossil 的个人博客, 8 October 2010. Available here: http://blog.sciencenet.cn/blog-225931370754.html (accessed 22 December 2020).

Yang, Huimin 杨惠民 and Jianye Yang 杨建业 (1983). “Di yi pi boshi huodezhe biaoshi: jixu pandeng kexue gaofeng; boshi de daoshimen zhicu: woguo you nengli peiyang gaoji zhuanmen rencai 第一批博士获得者表示 : 继续攀登科学高峰博 士的导师们指出 : 我国有能力培养高级专门人才 (The first batch of doctoral awardees say they will continue to climb the peaks of science; Ph.D. supervisors observe that our country has the ability to train advanced specialized talent)." Renmin ribao 5 May 1983, p. 3.

Cite this article: Ghosh A (2022). Trans-Himalayan science in mid-twentieth century China and India: Birbal Sahni, Hsü Jen, and a Pan-Asian paleobotany. International Journal of Asian Studies 19, 239-261. https://doi.org/10.1017/ S1479591421000292 